Research Article

\title{
Experimental Study on Diffusion Process of Sulfate Ion in Cemented Gangue Backfill Material
}

\author{
Yuxia Guo $\mathbb{D}^{1,2}$ Peng Wang, ${ }^{1,2}$ Guorui Feng $\mathbb{D}^{1,2}$ Tingye Qi $\mathbb{D}^{1,2}$ Xianjie Du ${ }^{1,}{ }^{1,2}$ \\ Zehua Wang $\left(\mathbb{D},{ }^{1,2}\right.$ and Qingdong $\operatorname{Li} \mathbb{B}^{1,2}$ \\ ${ }^{1}$ College of Mining Engineering, Taiyuan University of Technology, Taiyuan 030024, China \\ ${ }^{2}$ Shanxi Province Research Centre of Green Mining Engineering Technology, Taiyuan 030024, China \\ Correspondence should be addressed to Guorui Feng; fgr09000@126.com
}

Received 7 October 2019; Accepted 17 January 2020; Published 10 March 2020

Academic Editor: Robert Černý

Copyright (c) 2020 Yuxia Guo et al. This is an open access article distributed under the Creative Commons Attribution License, which permits unrestricted use, distribution, and reproduction in any medium, provided the original work is properly cited.

Cemented gangue backfill material (CGBM) is made of coal gangue, fly ash, cement, and water. The backfill body will be corroded by mine water that contains different kinds of corrosive ions. The paper mainly aimed to study the diffusion process of sulfate ion $\left(\mathrm{SO}_{4}^{2-}\right)$ in CGBM. Soluble salt solutions with different concentrations are prepared to simulate various mine water. The $\mathrm{SO}_{4}^{2-}$ concentration was measured by layered sampling method and chemical analyzing method. The diffusion coefficient was calculated according to the second Fick's law. Scanning electron microscope (SEM) and X-ray diffraction (XRD) were used to analyze the degradation mechanisms. The experimental results showed that the $\mathrm{SO}_{4}^{2-}$ concentration increases in CGBM when the external sulfate solutions concentration increases. With the increasing of magnesium ion $\left(\mathrm{Mg}^{2+}\right)$ concentration and bicarbonate ion $\left(\mathrm{HCO}_{3}^{-}\right)$concentration in the external corrosion solutions, the diffusion coefficient of $\mathrm{SO}_{4}^{2-}$ was increased, and $\mathrm{HCO}_{3}^{-}$has more significant effects than $\mathrm{Mg}^{2+}$. $\mathrm{SO}_{4}^{2-}$ reacting with CGBM produced ettringite and gypsum. The ettringite and gypsum changed the pore structure of hardened CGBM and affected the compressive strength of hardened CGBM. Studying the diffusion of $\mathrm{SO}_{4}^{2-}$ can contribute to predicting the service life of CGBM.

\section{Introduction}

Backfill mining is taken to solve the problem of surface subsidence caused by underground coal mining [1]. It has many benefits, such as reducing the accumulation of solid waste, and the occupation of cultivated land, developing and utilizing underground space [2], and protecting groundwater and environment [3]. Cemented gangue backfill material (CGBM), one of the common backfill materials, is made of coal gangue, fly ash, cement, and water [4]. Comparing to other backfill materials, the main raw materials of CGBM, such as coal gangue and fly ash, are plentiful and cheap, and its performance meets the workability and strength requirements of mining.

Due to the different levels of mine water, which contain different kinds of corrosive ions in the mine, the backfill body will be corroded by mine water during the service period. Zhang et al. found that the composition of mine water under the mine was complex and diverse, and most of them have $\mathrm{SO}_{4}^{2-}, \mathrm{HCO}_{3}^{-}, \mathrm{Cl}^{-}, \mathrm{Mg}^{2+}, \mathrm{Na}^{+}$, and $\mathrm{Ga}^{2+}$ [5]. The mine water composition of 37 measuring points in 12 mining areas in Shanxi and Inner Mongolia was investigated. Most of the mine water contains corrosive ions such as $\mathrm{Mg}^{2+}, \mathrm{HCO}_{3}^{-}$, and $\mathrm{SO}_{4}^{2-}$, and the ion concentration in the mine water varies greatly. The concentrations of $\mathrm{Mg}^{2+}$, $\mathrm{HCO}_{3}^{-}$, and $\mathrm{SO}_{4}^{2-}$ are $3.88 \sim 225.00 \mathrm{mg} / \mathrm{L}$, $221.000 \sim 3446.045 \mathrm{mg} / \mathrm{L}$, and $73.89 \sim 3314.00 \mathrm{mg} / \mathrm{L}$, respectively. These ions can be detrimental for hydrated cement in an aqueous environment and for integrity of backfill material consequently [6]. Therefore, it is essential to understand the diffusion process of corrosive ion and the deterioration mechanism of the compressive strength of backfill body.

Scholars have conducted a lot of research on the influence of corrosive media on the strength of cement-based materials. Fall et al. found that the strength of the backfill 
materials under sulfate attack is related to the concentration of sulfate solution, the amount of cement, and the chemical composition [7]. Sun et al. found that the change of backfill body strength under $\mathrm{Cl}^{-}, \mathrm{SO}_{4}^{2-}$, and $\mathrm{Mg}^{2+}$ corrosion is divided into slow growth segment and accelerated reduction segment, and the greater the concentration, the greater the reduction in strength [8]. Zhao et al. found that the strength of concrete increases first and then decreases in $\mathrm{Na}_{2} \mathrm{SO}_{4}$ and $\mathrm{Na}_{2} \mathrm{SO}_{4}$ and $\mathrm{NaHCO}_{3}$ complex salt solution and the concrete strength loss rate in the composite solution is greater than the single solution [9].

The effective section size of the backfill body will be reduced under corrosive mine water corrosion, and then the bearing capacity will be reduced, which lead the instability to occur. Exploring the diffusion process of corrosive ions inside materials is the basis for determining the redundancy of the section size as the backfill design. Benoit et al. found that sulfate attack was a diffusion reaction process of concrete when exposed to environment with sulfate [10]. Wang et al. immersed cement mortar in sulfate solutions used layered sampling method combined with chemical analysis, and calculated diffusion coefficients of $\mathrm{SO}_{4}^{2-}$ used XRD and SEM to analyze the formation of reaction products. The experimental results showed that in different kinds of sulfate solutions, cement mortars were immersed in $(\mathrm{NH} 4)_{2} \mathrm{SO}_{4}$ solutions firstly, $\mathrm{MgSO}_{4}$ solutions took the second place, and $\mathrm{Na}_{2} \mathrm{SO}_{4}$ solutions are the last [11]. Zuo and Sun found the $\mathrm{SO}_{4}^{2-}$ concentration in the concrete had a gradual increase with the increase of diffusion time; finally, the diffusion and reaction reach a dynamic equilibrium [12]. Idiart et al. accounted for the effect of discrete cracks on the transport of ions, and experimental observation indicated ettringite penetration to make an impact on crack propagation [13]. Tai et al. considered that the distribution of pores had influence for the diffusion of $\mathrm{SO}_{4}^{2-}$ in concrete specimens. Ettringite could fill pores, which would change the diffusion path of the ions [14].

Some scholars have establishing models about diffusion coefficient. Nicola et al. used external sulfate to attack concrete structures under partially or fully saturated conditions and established a diffusion model to account for chemical and mechanical damage $[15,16]$. In order to calculate the chloride diffusion coefficient (D) in concrete, 3 factors (chloride concentration, curing, and environment temperature) were considered and used to predict concrete's life of service $[17,18]$. Wang et al. used Fick's second law to calculate diffusion coefficient of chloride ion [19-21].

Corrosion of backfill materials by soluble salts is a complex physical and chemical process. Revealing the performance degradation mechanism of backfill materials under corrosive action plays an important role in understanding the deterioration of material properties. Fall et al. found that C-S-H gel in tailings cemented filler material absorbs sulfate and causes its structural quality to decline. The expanded mineral ettringite in the pores of the paste material dissolves at high temperature to roughen the pores of the paste [22]. A few investigators found sulfate attack produced ettringite, and this process had two stages. The ettringite was strengthened due to its crystallization in the first stage; the ettringite was weakened because of overexpansion and modeling to verify its rationality and validity in the second stage $[23,24]$. Some investigators also used high resolution synchrotron X-ray diffraction (SyXRD) to analyze microstructural profile of concrete deterioration which was attacked by sulfate [25-27].

At present, a lot of researches have been carried out on the strength and corrosive ion diffusion laws of cementbased composite materials such as concrete under salt corrosion environment, and especially the research results of concrete materials are fruitful. But at the same time, it can be found that due to various materials, different corrosive media and test methods, various factors, and research results varying widely, only qualitative results or laws can be referenced and borrowed, and special research should be carried out for different materials in combination with actual working conditions.

The main objective of this paper is to study the diffusion process of $\mathrm{SO}_{4}^{2-}$ and investigate the relationship between compressive strength and diffusion and analyze the products using XRD and SEM. The paper also considers the time factor to establish a prediction model which is about CGBM's length of service, which can contribute to predicting the service life of CGBM.

\section{Materials and Methods}

2.1. Raw Materials. For ordinary Portland cement (CEM I $42.5 \mathrm{~N}$ ) (binary system), the initial and final setting time were $165 \mathrm{~min}$ and $231 \mathrm{~min}$, respectively, and the compressive strength was $21.9 \mathrm{MPa}$ ( $3 \mathrm{~d}$ curing time) and 54.1 MPa (28 d curing. time). The fly ash sample was obtained from the power plant of Xinyang Colliery, a mine in Shanxi Province of China. The coal gangue samples were obtained from Xinyang Colliery, through breaking, and divided into fine aggregate $(<5 \mathrm{~mm})$ and coarse aggregate $(5 \sim 15 \mathrm{~mm})$ through breaking; their chemical compositions and physical properties are listed in Table 1. The mixture proportion of CGBM is shown in Table 2.

\subsection{Salt Solution Corrosion Experiments}

2.2.1. Specimen's Preparation. The specimen's preparation was according to Chinese standard GB/T50081-2002. The cube specimens with size of $100 \mathrm{~mm} \times 100 \mathrm{~mm} \times 100 \mathrm{~mm}$ were casted. The specimens were cured under the temperature of $23 \pm 2^{\circ} \mathrm{C}$ and $\mathrm{RH}$ was not less than $90 \%$ in molds for 24 hours. Then the specimens were demolded and cured in water under the temperature of $23 \pm 1^{\circ} \mathrm{C}$ for 28 days. Namely, curing time of specimens was 28 days before the immersion test. Specimens were sealed with epoxy resin on the five opposite sides, and one side was exposed to subsequent sulfate attack experiments [11].

2.2.2. Salt Solution Corrosion Conditions. Specimens were soaked in different salt solutions; salt mediums were sodium sulfate $\left(\mathrm{Na}_{2} \mathrm{SO}_{4}\right)$ solutions, magnesium sulfate $\left(\mathrm{MgSO}_{4}\right)$ solution, and sodium bicarbonate $\left(\mathrm{NaHCO}_{3}\right)$ solution; and 
TABLE 1: Chemical and physical properties of the main raw materials of CGBM [4].

\begin{tabular}{lccc}
\hline Major element & Cement (\%) & Fly ash (\%) & Gangue (\%) \\
\hline $\mathrm{SiO}_{2}$ & 22.36 & 52.42 & 35.46 \\
$\mathrm{Al}_{2} \mathrm{O}_{3}$ & 5.53 & 32.48 & 16.11 \\
$\mathrm{Fe}_{2} \mathrm{O}_{3}$ & 3.46 & 3.62 & 3.86 \\
$\mathrm{CaO}$ & 65.08 & 0.99 & 7.15 \\
$\mathrm{MgO}$ & 2.1 & 1.01 & 3.50 \\
$\mathrm{TiO}_{2}$ & - & 1.26 & 0.80 \\
Specific gravity & 3.1 & 2.2 & 2.0 \\
Specific surface $\left(\mathrm{m}^{2} / \mathrm{kg}\right)$ & 372 & 415 & 499 \\
Fineness $(>45 \mu \mathrm{m})(\%)$ & 5 & 42.54 & 53.78 \\
\hline
\end{tabular}

TABLE 2: Proportion of CGBM mixture.

\begin{tabular}{lcccc}
\hline $\begin{array}{l}\text { Cement } \\
\left(\mathrm{kg} \cdot \mathrm{m}^{-3}\right)\end{array}$ & $\begin{array}{c}\text { Fly ash } \\
\left(\mathrm{kg} \cdot \mathrm{m}^{-3}\right)\end{array}$ & $\begin{array}{c}\text { Coal gangue } \\
\text { Fine } \\
\text { aggregate }\end{array}$ & $\begin{array}{c}\text { Coarse } \\
\text { aggregate }\end{array}$ & $\begin{array}{c}\text { Mass } \\
\text { concentration } \\
(\%)\end{array}$ \\
\hline 190 & 380 & 285 & 665 & 80
\end{tabular}

the proportions of these solutions are listed in Table 3. S3, S5, and $\mathrm{S} 10$ represent $3 \%, 5 \%$, and $10 \% \mathrm{Na}_{2} \mathrm{SO}_{4}$ solutions; $\mathrm{M} 3$ and $\mathrm{M} 5$ represent $3 \%$ and $5 \% \mathrm{MgSO}_{4}$ solutions; and $\mathrm{H} 3$ and $\mathrm{H} 5$ represent $3 \%$ and $5 \% \mathrm{NaHCO}_{3}$ solutions. To keep the concentration constant, the solutions were renewed for three days.

2.2.3. Layered Sampling Method. Specimens immersed in different salt solutions at the schedule age $(30 \mathrm{~d} / 60 \mathrm{~d} / 120 \mathrm{~d} /$ $180 \mathrm{~d}$ ) were taken out and dried under the temperature of $60^{\circ} \mathrm{C}$ for about 24 hours to make the surface dry and easily sampled. Then every $3 \mathrm{~mm}$ layered sampling was taken from the exposed surface to center by precision lathe and the powder samples were collected, respectively. After vacuum drying for 24 hours under the temperature of $105 \pm 5^{\circ} \mathrm{C}$, the samples were sealed for the next experiment. Cutting depth of each specimen was usually six layers which is $18-20 \mathrm{~mm}$. The test process is shown in Figure 1.

2.2.4. Determination of $\mathrm{SO}_{4}^{2-}$ of Specimens. Chemical analysis method was carried out to determine the sulfate ion $\left(\mathrm{SO}_{4}^{2-}\right)$ concentration of powder samples in different depths of specimens. Analysis method was according to Chinese standard GB/T 176-2008 "Methods for Chemical Analysis of Cement". The powder samples were collected by the method of layered sampling, weighed accurately, dissolved by hot hydrochloric acid and filtered. Then the filtrate and Barium chloride solution $\left(\mathrm{BaCl}_{2}\right)$ was mixed to produce precipitate which was filtered again, and weighed after drying under the $900^{\circ} \mathrm{C}[11]$.

$\mathrm{SO}_{4}^{2-}$ concentration was calculated according to the following:

$$
w\left(\mathrm{SO}_{4}^{2-}\right)=\frac{\left(m_{2}-m_{1}\right) \times 0.4116}{m} \times 100 \%,
$$

TABLE 3: Ratio of salt solutions.

\begin{tabular}{lccc}
\hline Ion name & $\mathrm{Na}_{2} \mathrm{SO}_{4}$ & $\mathrm{MgSO}_{4}$ & $\mathrm{NaHCO}_{3}$ \\
\hline $\mathrm{N}$ & 0 & 0 & 0 \\
$\mathrm{~S} 3$ & $3 \%$ & 0 & 0 \\
$\mathrm{~S} 5$ & $5 \%$ & 0 & 0 \\
$\mathrm{~S} 10$ & $10 \%$ & 0 & 0 \\
$\mathrm{~S} 5+\mathrm{M} 3$ & $2 \%$ & $3 \%$ & 0 \\
$\mathrm{~S} 5+\mathrm{M} 5$ & 0 & $5 \%$ & 0 \\
$\mathrm{~S} 5+\mathrm{H} 3$ & $5 \%$ & 0 & $3 \%$ \\
$\mathrm{~S} 5+\mathrm{H} 5$ & $5 \%$ & 0 & $5 \%$ \\
S5 + M5+H5 & 0 & $5 \%$ & $5 \%$ \\
\hline
\end{tabular}

where $m$ is the mass of powder sample, $g$; $m_{1}$ is the mass of crucible, $g$; and $m_{2}$ is the total mass of precipitate and crucible, $g$.

2.2.5. Testing Compressive Strength. Compressive strength test was conducted with a YAW-200B-type compressiontesting machine. The load was implemented at a relatively slow rate $(0.3 \mathrm{KN} / \mathrm{s})$. Each test was repeated at least three times and the average value was calculated as the compressive strength of specimens.

2.2.6. Diffusion Coefficient Calculation of $\mathrm{SO}_{4}^{2-}$. Fick's second law of diffusion was widely used to describe kinds of ions diffusion into concrete [18]. In general, the diffusion of $\mathrm{SO}_{4}^{2-}$ in CGBM obeyed Fick's second law. In this paper, the CGBM was assumed as a semi-infinite homogeneous medium and $\mathrm{SO}_{4}^{2-}$ was not bound to material when they diffused, so the coefficient of $\mathrm{SO}_{4}^{2-}$ was constant [28], and the following one-dimensional equation was used:

$$
\frac{\partial C}{\partial t}=D_{c} \frac{\partial^{2} C}{\partial x^{2}}
$$

where $C$ is the $\mathrm{SO}_{4}^{2-}$ concentration, $\mathrm{cm}^{2} / \mathrm{s} ; t$ is the period of corrosion, $s ; x$ is the corrosion depth, $\mathrm{cm}$; and $D$ is the diffusion coefficient, $\mathrm{cm}^{2} / \mathrm{s}$.

When the initial condition was $t=0, x>0, C=0$; boundary condition was $x=0, t>0, C=C_{s}$. The solutions were evolved into the following equation:

$$
C(x, t)=C_{s}\left[1-\operatorname{erf}\left(\frac{x}{2 \sqrt{D_{c} t}}\right)\right],
$$

where $C_{s}$ is the concentration of $\mathrm{SO}_{4}^{2-}$ on the surface, $\mathrm{cm}^{2} / \mathrm{s}$, and erf is the error function, erf $=(2 / \sqrt{\pi}) \int_{0}^{u} e^{-t^{2}} \mathrm{~d} t$.

Then diffusion coefficient was evolved into the following equations:

$$
\begin{aligned}
D_{i} & =\frac{x_{i}^{2}}{2 t\left[\Phi^{-1}\left(m_{i}\right)\right]^{2}}, \\
m_{i} & =\frac{1}{2 \sqrt{2}}\left[1-\frac{C_{i}(x, t)}{C_{s}}\right]+0.5,
\end{aligned}
$$

where $\Phi^{-1}\left(m_{i}\right)$ can be traceable standard normal distribution table. 


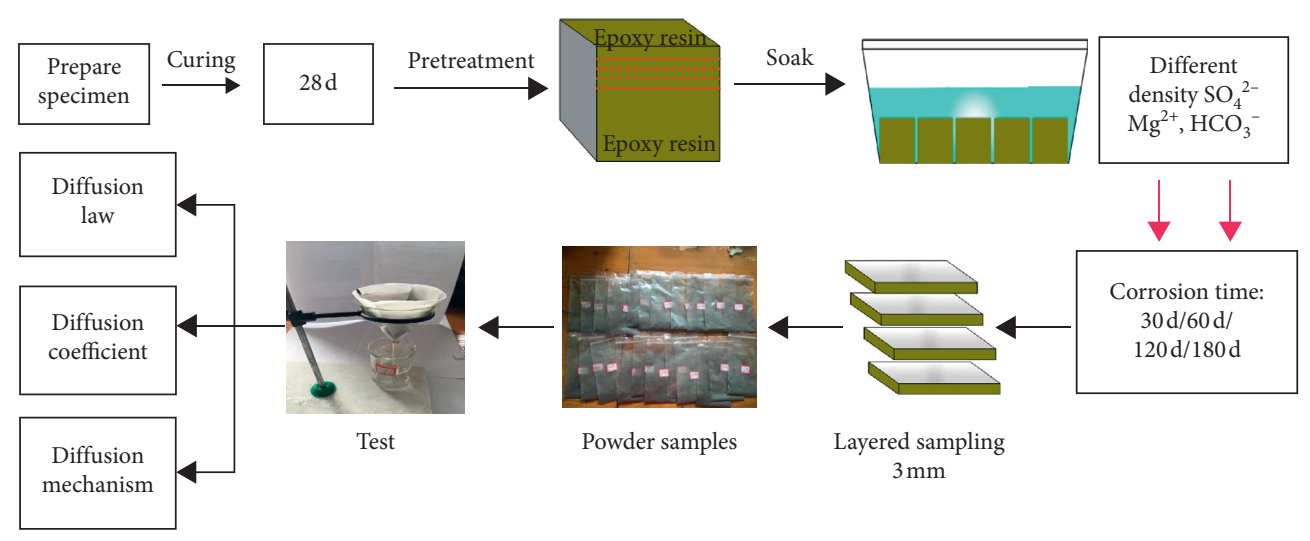

Figure 1: Test process.

The $\mathrm{SO}_{4}^{2-}$ concentration on the surface and coefficient of variation was evolved into the following equations:

$$
\begin{aligned}
E(D) & =\frac{\sum_{i=1}^{n} D_{i}}{n}, \\
\operatorname{Var}(D) & =\left|\frac{\left(\sum_{i=1}^{n} D_{i}^{2}-n E^{2}(D)\right)}{n-1}\right|,
\end{aligned}
$$

where $n$ is the number of measured points of the specimen and Var is the coefficient of variation.

\section{Results and Discussion}

3.1. Influence of Concentration in Diffusion. Specimens were immersed in $3 \%, 5 \%$, and $10 \% \mathrm{Na}_{2} \mathrm{SO}_{4}$ solutions; $\mathrm{SO}_{4}^{2-}$ concentration at different depths in the specimen was obtained according to the above method. The results are shown in Figure 2.

It can be seen that the closer to the surface of the specimens, the higher the concentration of $\mathrm{SO}_{4}^{2-}$. The $\mathrm{SO}_{4}^{2-}$ concentration is decreased with increasing depth of specimens. And the deceleration rate is faster before $6 \mathrm{~mm}$. The $\mathrm{SO}_{4}^{2-}$ concentration in the specimens decreases slowly and linearly after $6 \mathrm{~mm}$. Because $\mathrm{SO}_{4}^{2-}$ reacts with $\mathrm{CGBM}$ to form gypsum and ettringite, the product will block the surface pores of the materials and change the ion diffusion path, leading to rapid decrease in ion diffusion rate and then slowing down $[6,14]$. At 180 days, when the concentration of the external solution $\mathrm{Na}_{2} \mathrm{SO}_{4}$ solution is $3 \%, 5 \%$, and $10 \%$, the $\mathrm{SO}_{4}^{2-}$ concentration is $0.4634 \%, 0.5215 \%$, and $0.6712 \%$ from the surface of the specimens at $3 \mathrm{~mm} . \mathrm{SO}_{4}^{2-}$ of high concentration in external solution can accelerate the ion diffusion, which indicates that the reaction product is increased, so that the internal pores are expanded in CGBM [29].

3.2. Influence of Different Kinds of Salt Solutions in Diffusion. Specimens were immersed in $\mathrm{Na}_{2} \mathrm{SO}_{4}+\mathrm{MgSO}_{4}$, $\mathrm{Na}_{2} \mathrm{SO}_{4}+\mathrm{NaHCO}_{3}$, and $\mathrm{Na}_{2} \mathrm{SO}_{4}+\mathrm{MgSO}_{4}+\mathrm{NaHCO}_{3}$ composite solution; $\mathrm{SO}_{4}^{2-}$ concentration at different depths in the specimen was obtained according to the above method. The results are shown in Figure 3.
It can be seen that the change trend of $\mathrm{SO}_{4}^{2-}$ concentration is basically consistent with single sulfate corrosion; all of them presented the trend that $\mathrm{SO}_{4}^{2-}$ concentration is high in outside section and low in inside section. At the same corrosion depth, the concentrations of $\mathrm{Mg}^{2+}$ and $\mathrm{HCO}_{3}^{-}$are higher in the external composite solutions, and concentration of $\mathrm{SO}_{4}^{2-}$ is higher in the specimens. As is shown in Figures 3(a)-3(e), at 180 days, the $\mathrm{SO}_{4}^{2-}$ concentrations are $0.495 \%, 0.5373 \%, 0.5291 \%, 0.6011 \%$, and $6471 \%$ from the surface of the specimens at $3 \mathrm{~mm}$. It can be found that when the concentration of $\mathrm{MgSO}_{4}$ solution is 3\% in external solution, the diffusion of $\mathrm{SO}_{4}^{2-}$ is inhibited, and when the concentration is $5 \%$, it will accelerate the diffusion of $\mathrm{SO}_{4}^{2-}$. When the external solution contains $\mathrm{HCO}_{3}^{-}$, it also accelerates the diffusion of $\mathrm{SO}_{4}^{2-}$. And the effect is greater than that of $\mathrm{Mg}^{2+}$. When both ions are present at the same time, the effect is the greatest.

Comparison of $\mathrm{SO}_{4}^{2-}$ concentrations at depth $15 \mathrm{~mm}$ distance from CGBM surface in $\mathrm{Na}_{2} \mathrm{SO}_{4}, \mathrm{Na}_{2} \mathrm{SO}_{4}+\mathrm{MgSO}_{4}$, $\mathrm{Na}_{2} \mathrm{SO}_{4}+\mathrm{NaHCO}_{3}$, and $\mathrm{Na}_{2} \mathrm{SO}_{4}+\mathrm{MgSO}_{4}+\mathrm{NaHCO}_{3}$ composite solution are shown in Figure 4.

Effects of different ions on diffusion coefficient of $\mathrm{SO}_{4}^{2-}$ in specimens are shown in Figure 5. The changed trend of its diffusion coefficient is divided into two stages: a fast-linear falling section at 30-60 d and a slow falling section after $60 \mathrm{~d}$. The precorrosion period is due to the reaction product blocking the surface pores of the specimens $[11,14]$, so that the diffusion coefficient is rapidly reduced. As the corrosion time increases, the concentration difference between the inside and the outside gradually becomes balanced, so the diffusion rate slowly decreases.

By changing the external solutions from $5 \% \mathrm{Na}_{2} \mathrm{SO}_{4}$ solutions to $5 \% \mathrm{Na}_{2} \mathrm{SO}_{4}+3 \% \mathrm{MgSO}_{4}$ composite solutions, as can be seen from Figure $4(\mathrm{a})$, the $\mathrm{SO}_{4}^{2-}$ concentration is decreased by $23 \%, 35 \%, 17 \%$, and $8 \%$ in $30-, 60-, 120-$, and 180-day specimens, respectively. As can be seen from Figure 5(a), the diffusion coefficient of $\mathrm{SO}_{4}^{2-}$ is decreased by $19 \%, 13 \%$, and $4 \%$ and increased by $15 \%$ in 30-, 60-, 120-, and 180-day specimens, respectively. At the early age, whether $\mathrm{MgSO}_{4}$ solution is less than $3 \%$ can be found, which can inhibit the diffusion of $\mathrm{SO}_{4}^{2-}$ in CGBM. That is because a small amount of $\mathrm{Mg}^{2+}$ enters into CGBM in the early age and reacts with the hydration product to form brucite 


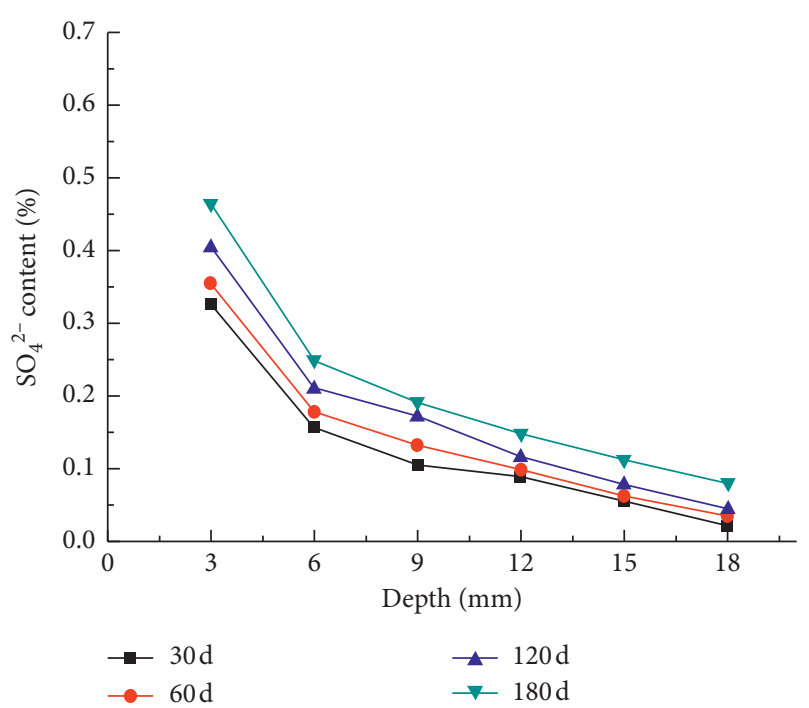

(a)

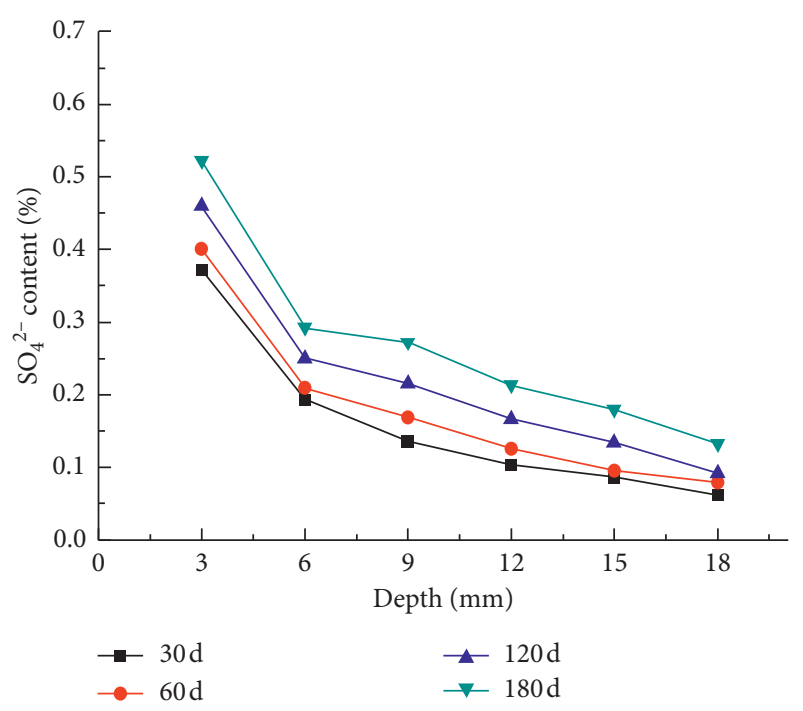

(b)

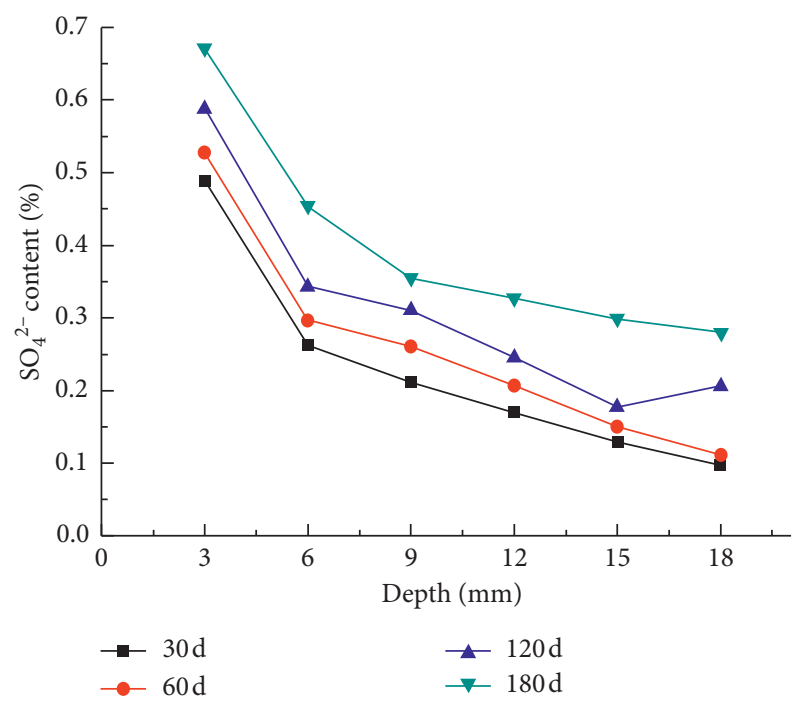

(c)

Figure 2: The relationship between $\mathrm{SO}_{4}{ }^{2-}$ concentration and immersion time at different diffusion depths. (a) $3 \% \mathrm{Na}_{2} \mathrm{SO}_{4}^{-}$, (b) $5 \% \mathrm{Na}_{2} \mathrm{SO}_{4}$, and (c) $10 \% \mathrm{Na}_{2} \mathrm{SO}_{4}$.

$\left(\mathrm{Mg}(\mathrm{OH})_{2}\right) ; \mathrm{M}-\mathrm{H}-\mathrm{S}$ and $\mathrm{SO}_{4}^{2-}$ enter into CGBM to form gypsum and ettringite $[13,25]$. These are all water-insoluble precipitate, which can fill the pores of CGBM to improve its compressive strength and prevent $\mathrm{SO}_{4}^{2-}$ to penetrate $[29,30]$. As time goes on, $\mathrm{SO}_{4}^{2-}$ penetrates the pores gradually and reactants increase, which leads to internal crack expansion in CGBM [31]. Lastly, it will accelerate the diffusion of ions, and the compressive strength decreases.

By changing the external solutions from $5 \% \mathrm{Na}_{2} \mathrm{SO}_{4}$ solutions to $5 \% \mathrm{Na}_{2} \mathrm{SO}_{4}+5 \% \mathrm{MgSO}_{4}$ composite solutions, from Figure 4(a), the $\mathrm{SO}_{4}^{2-}$ concentration is increased by $5 \%$, $15 \%, 21 \%$, and $25 \%$ in $30-, 60-, 120-$, and 180 -day specimens, respectively. From Figure 5(a), the diffusion coefficient of $\mathrm{SO}_{4}^{2-}$ is increased by $0.1 \%, 11 \%, 23 \%$, and $49 \%$ in $30-, 60-, 120$ , and 180-day specimens, respectively. Compared with the previous groups, when $\mathrm{MgSO}_{4}$ solution is more than $5 \%$ can accelerate the diffusion of $\mathrm{SO}_{4}^{2-}$ in CGBM. According to the data, with the corrosion time prolonging, the $\mathrm{SO}_{4}^{2-}$ concentration is much more in CGBM, and the diffusion coefficient of $\mathrm{SO}_{4}^{2-}$ is also increasing correspondingly because the reaction product increases, expands the crack of CGBM, and increases the channel of ions diffusion $[14,25,26]$.

By changing the external solutions from $5 \% \mathrm{Na}_{2} \mathrm{SO}_{4}$ solutions to $5 \% \mathrm{Na}_{2} \mathrm{SO}_{4}+3 \% \mathrm{NaHCO}_{3}$ composite solutions, from Figure 4(b), the $\mathrm{SO}_{4}^{2-}$ concentration is increased by $1 \%$, $9 \%, 16 \%$, and $12 \%$ in $30-, 60-, 120$-, and 180 -day specimens, respectively. From Figure 5(b), the diffusion coefficient of $\mathrm{SO}_{4}^{2-}$ is increased by $0.1 \%, 12 \%, 19 \%$, and $40 \%$ in $30-, 60-, 120-$, and 180-day specimens, respectively. Because $\mathrm{HCO}_{3}^{-}$enters into CGBM and reacts with it to produce a new corrosion product, which is thaumasite and $\mathrm{C}-\mathrm{S}-\mathrm{H}$, internal structure is damaged severely more than single sulfate attacks $[13,22]$. At the same time, Portland cement contains much $\mathrm{C}_{2} \mathrm{~S}$ which provides enough reactants for thaumasite formation [11]. 

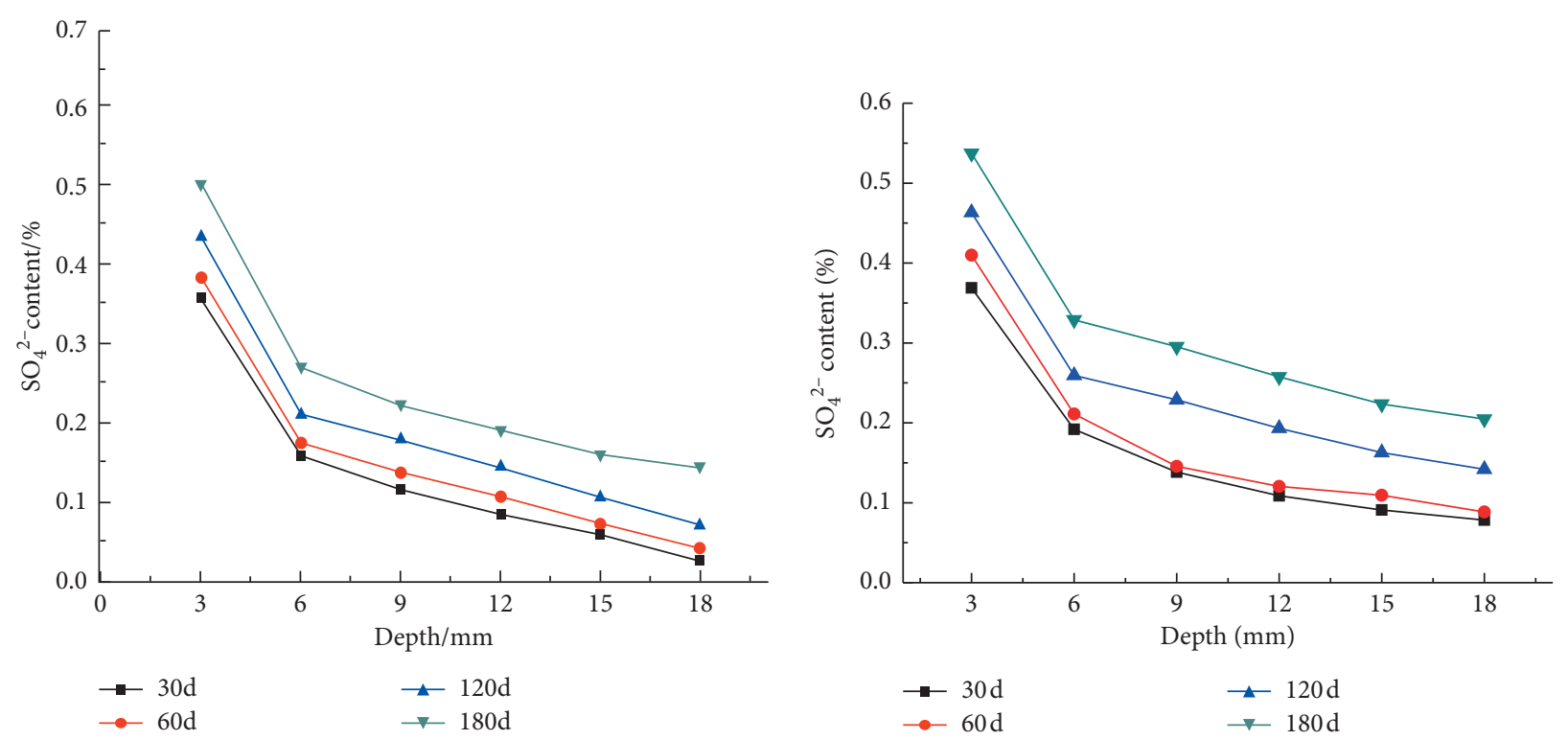

(a)

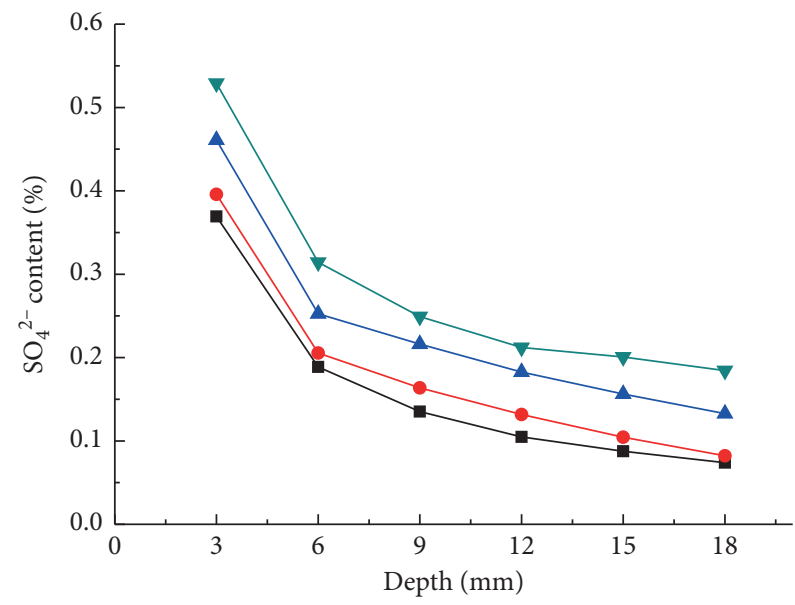

(b)
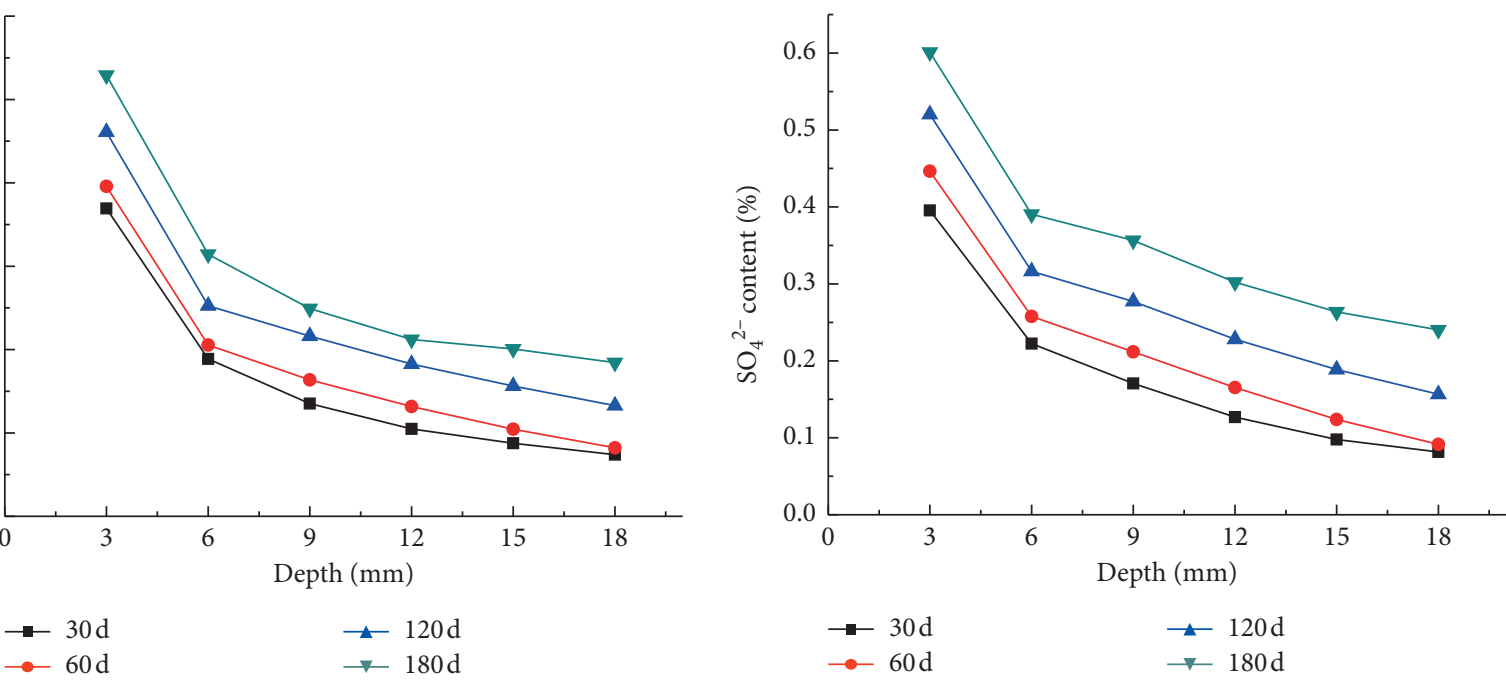

$$
\rightarrow 120 \mathrm{~d}
$$$$
\rightarrow 30 \mathrm{~d}
$$$$
\leftarrow 120 \mathrm{~d}
$$

$\rightarrow 60 \mathrm{~d}$

$\rightarrow 180 \mathrm{~d}$

(c)

(d)

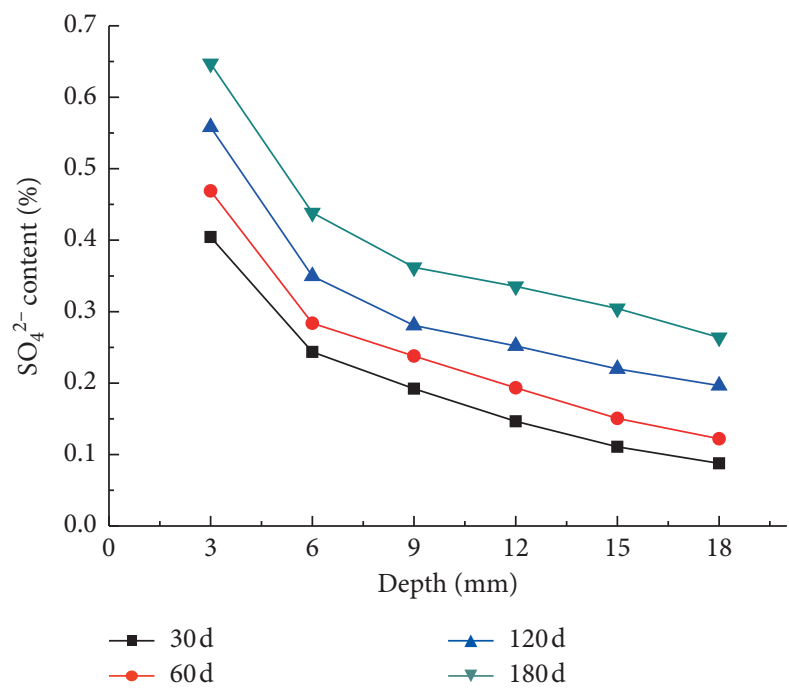

(e)

Figure 3: The relationship between $\mathrm{SO}_{4}^{2-}$ concentration and immersion time at different diffusion depths. (a) $5 \% \mathrm{Na}_{2} \mathrm{SO}_{4}+3 \% \mathrm{MgSO}_{4}$, (b) $5 \%$ $\mathrm{Na}_{2} \mathrm{SO}_{4}+5 \% \mathrm{MgSO}_{4}$, (c) $5 \% \mathrm{Na}_{2} \mathrm{SO}_{4}+3 \% \mathrm{NaHCO}_{3}$, (d) $5 \% \mathrm{Na}_{2} \mathrm{SO}_{4}+5 \% \mathrm{NaHCO}_{3}$, and (e) $5 \% \mathrm{Na}_{2} \mathrm{SO}_{4}+5 \% \mathrm{MgSO}_{4}+5 \% \mathrm{NaHCO}_{3}$. 


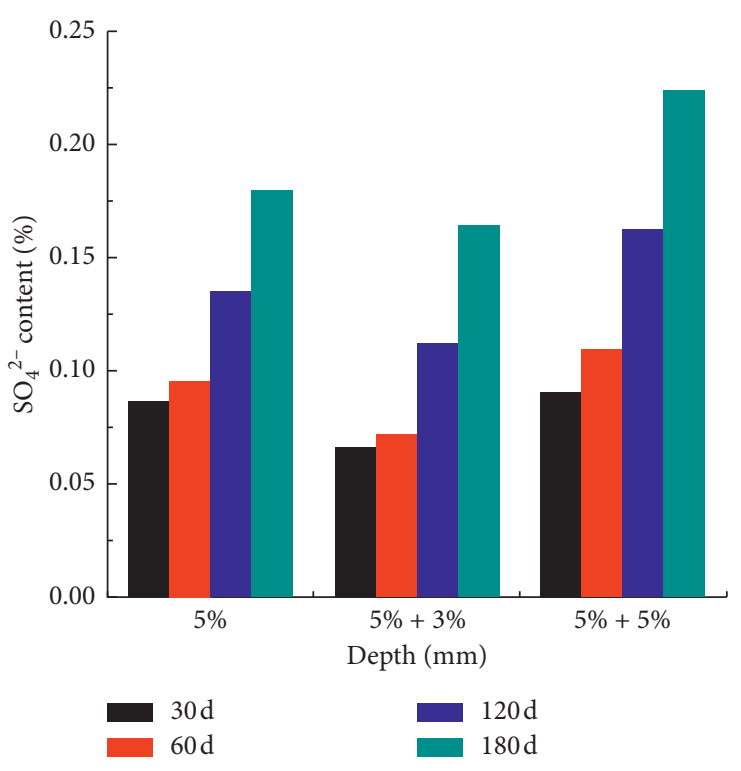

(a)

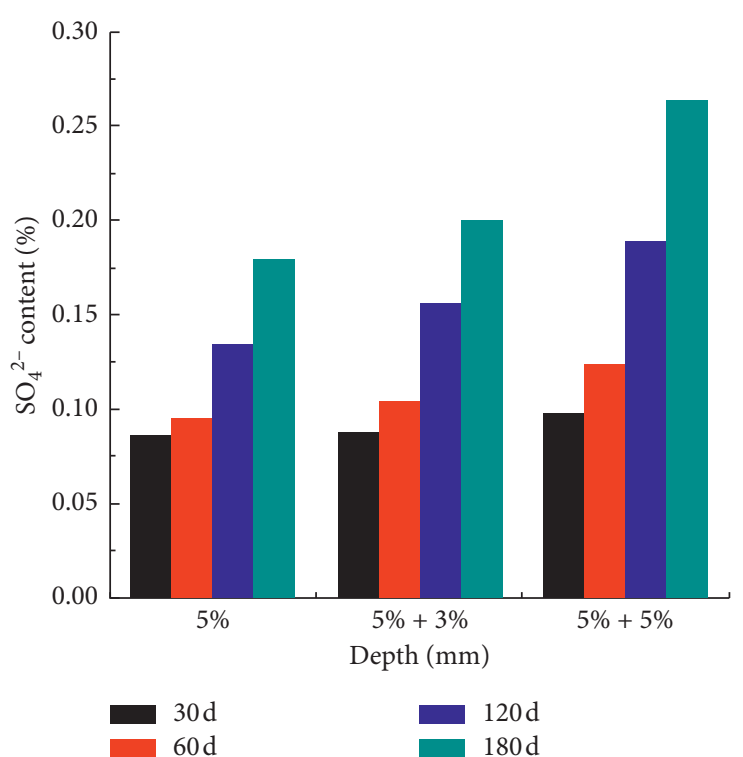

(b)

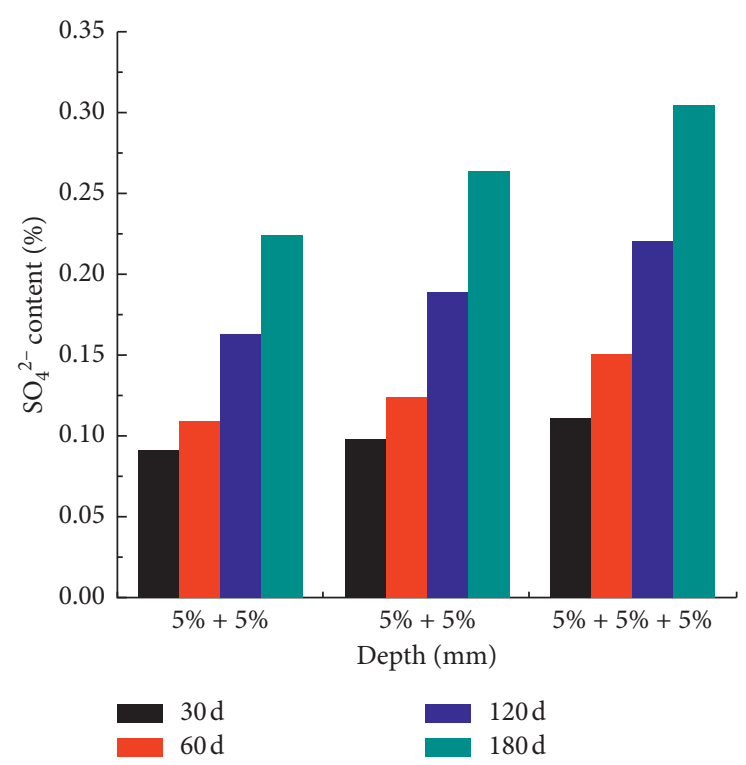

(c)

FIgURE 4: $\mathrm{SO}_{4}^{2-}$ concentration test results at $15 \mathrm{~mm}$. (a) $\mathrm{Na}_{2} \mathrm{SO}_{4}+\mathrm{MgSO}_{4}$, (b) $\mathrm{Na}_{2} \mathrm{SO}_{4}+\mathrm{NaHCO}_{3}$, and (c) $\mathrm{Na}_{2} \mathrm{SO}_{4}+5 \% \mathrm{MgSO}_{4}+5 \% \mathrm{NaHCO}_{3}$.

By changing the external solutions from $5 \% \mathrm{Na}_{2} \mathrm{SO}_{4}$ solutions to $5 \% \mathrm{Na}_{2} \mathrm{SO}_{4}+5 \% \mathrm{NaHCO}_{3}$ composite solutions, from Figure 4(b), the $\mathrm{SO}_{4}^{2-}$ concentration is increased by $13 \%, 30 \%, 40 \%$, and $47 \%$ in $30-, 60-, 120-$, and 180 -day specimens, respectively. From Figure 5(b), the diffusion coefficient of $\mathrm{SO}_{4}^{2-}$ is increased by $0.2 \%, 23 \%, 36 \%$, and $59 \%$ in 30-, 60-, 120-, and 180-day specimens, respectively. By comparing the data, single-doped $\mathrm{HCO}_{3}^{-}$has more influence than single-doped $\mathrm{Mg}^{2+}$ for the diffusion of $\mathrm{SO}_{4}^{2-}$.

By changing the external solutions from $5 \% \mathrm{Na}_{2} \mathrm{SO}_{4}+5 \%$ $\mathrm{MgSO}_{4}$ composite solutions to $5 \% \mathrm{Na}_{2} \mathrm{SO}_{4}+5 \% \mathrm{MgSO}_{4}+5 \%$ $\mathrm{NaHCO}_{3}$ composite solutions, from Figure 4(c), the $\mathrm{SO}_{4}^{2-}$ concentration is increased by $22 \%, 38 \%, 35 \%$, and $36 \%$ in 30 -, $60-, 120-$, and 180-day specimens, respectively. From Figure 5(c), the diffusion coefficient of $\mathrm{SO}_{4}^{2-}$ is increased by $7 \%$,
$23 \%, 19 \%$, and $16 \%$ in $30-, 60-, 120-$, and 180 -day specimens, respectively. By comparing the data, composite of the $\mathrm{HCO}_{3}^{-}$ and $\mathrm{Mg}^{2+}$ has more influence than single-doped $\mathrm{HCO}_{3}^{-}$or single-doped $\mathrm{Mg}^{2+}$ for the diffusion of $\mathrm{SO}_{4}^{2-}$.

The compressive strength results are shown in Figure 6. The compressive strength increases first and the then decreases. The precorrosion period is due to blocking the pores by the reaction product, which makes the material more solid $[7,8]$. As the corrosion time increases, the reaction product increases, which will expand the crack and lead to a decrease in strength [9].

3.3. Time Influences for Diffusion Coefficient of $\mathrm{SO}_{4}^{2-}$. According to what the diffusion coefficient of $\mathrm{SO}_{4}^{2-}$ shows, it can be concluded that it is not a constant, but a 


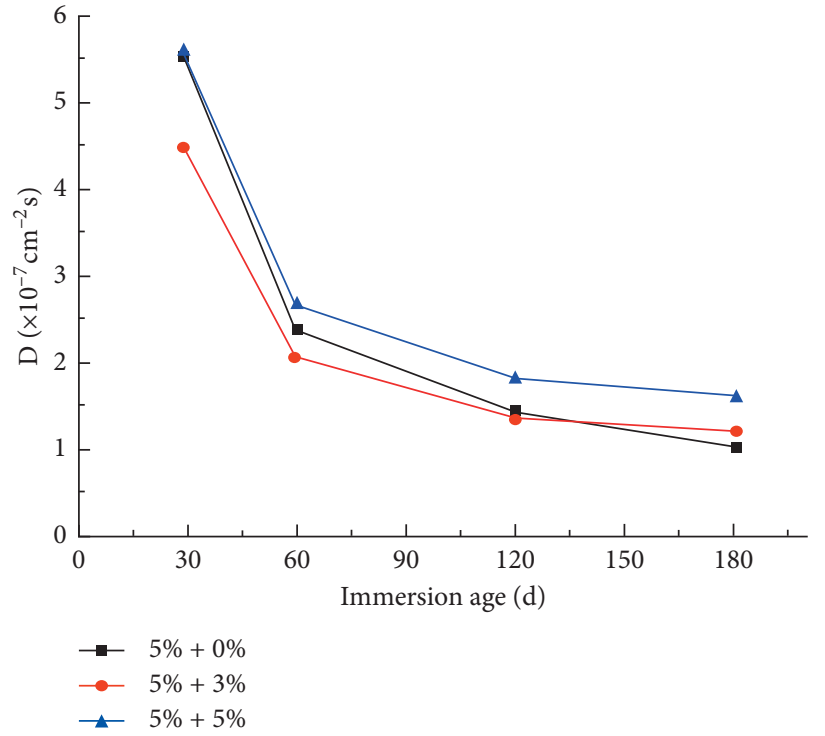

(a)

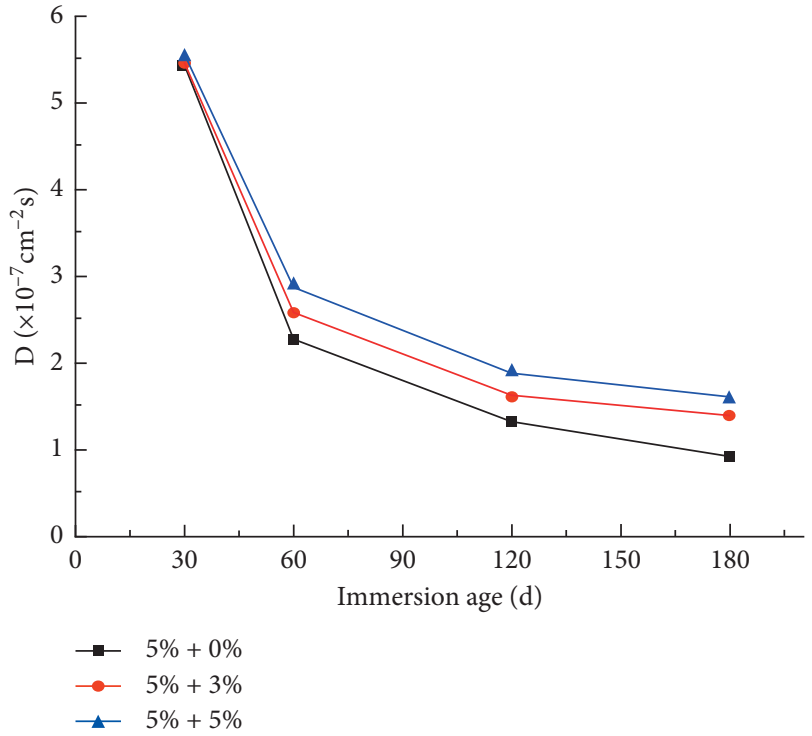

(b)

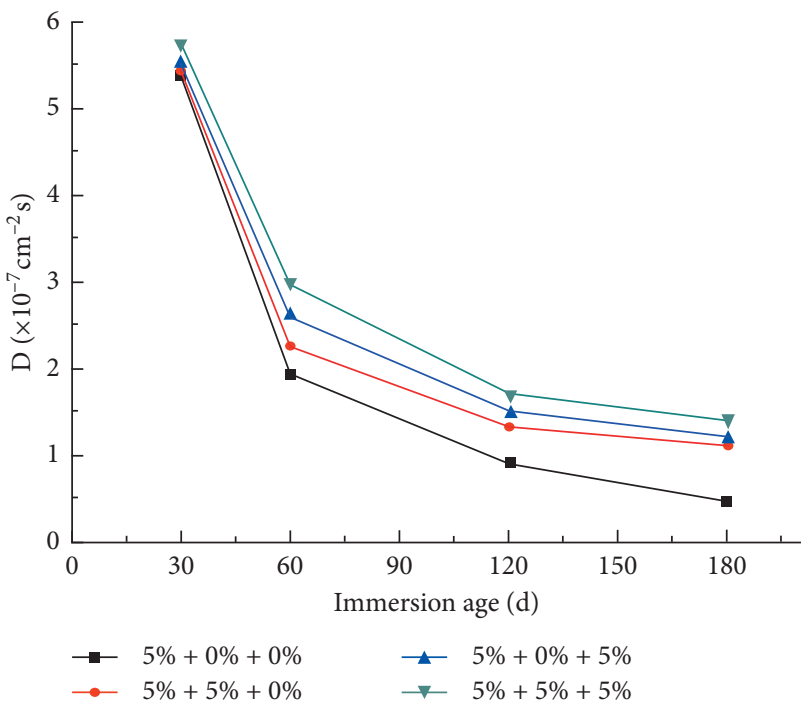

(c)

FIGURE 5: Effect of different ions on diffusion coefficient of $\mathrm{SO}_{4}{ }^{2-}$ in CGBM. (a) $\mathrm{Na}_{2} \mathrm{SO}_{4}+\mathrm{MgSO}_{4}$, (b) $\mathrm{Na}_{2} \mathrm{SO}_{4}+\mathrm{NaHCO}_{3}$, and (c) $\mathrm{Na}_{2} \mathrm{SO}_{4}+5 \%$ $\mathrm{MgSO}_{4}+5 \% \mathrm{NaHCO}_{3}$.

function is considered with time. The basic rule is that the diffusion coefficient decreases with time. Because CGBM is a hydraulic material, its internal structure changes over time. Therefore, equation (3) needs to consider the factor of time [32]. The diffusion coefficient of $\mathrm{SO}_{4}^{2-}$ changing with time is evolved into the following equation:

$$
D(t)=D_{1} t^{-m},
$$

where $D(t)$ is the diffusion coefficient of $\mathrm{SO}_{4}^{2-}$ at time $t, \mathrm{~cm}^{2} /$ year; $D_{1}$ is the diffusion coefficient of sulfate ion at 1 year, $\mathrm{cm}^{2} /$ year; and $m$ is the empirical coefficient.

Establishing a diffusion model to use diffusion coefficients $D_{1}, m$ and surface concentration $C_{s}$, the diffusion model evolves into the following equation:

$$
C(x, t)=C_{s}\left[1-\operatorname{erf}\left(\frac{x}{2 \sqrt{D_{1} t^{1-m} /(1-m)}}\right)\right] .
$$

The comparison between considering time and not considering time to observe the diffusion coefficients of $\mathrm{SO}_{4}^{2-}$ in CGBM is shown in Table 4. The model of diffusion under the composite solutions is shown in Table 5.

\section{Using XRD and SEM to Analyze Reaction Products in CGBM}

Reaction products of CGBM were immersed in $\mathrm{Na}_{2} \mathrm{SO}_{4}$, $\mathrm{Na}_{2} \mathrm{SO}_{4}+\mathrm{MgSO}_{4}, \quad \mathrm{Na}_{2} \mathrm{SO}_{4}+\mathrm{NaHCO}_{3}$ and $\mathrm{Na}_{2} \mathrm{SO}_{4}+$ $\mathrm{MgSO}_{4}+\mathrm{NaHCO}_{3}$ composite solution separately, then SEM 


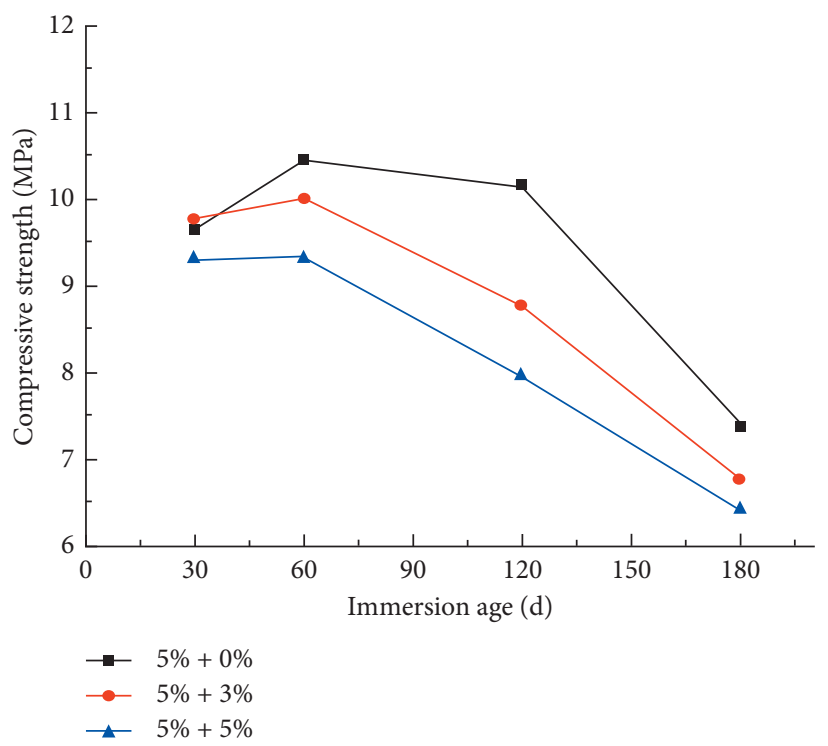

(a)

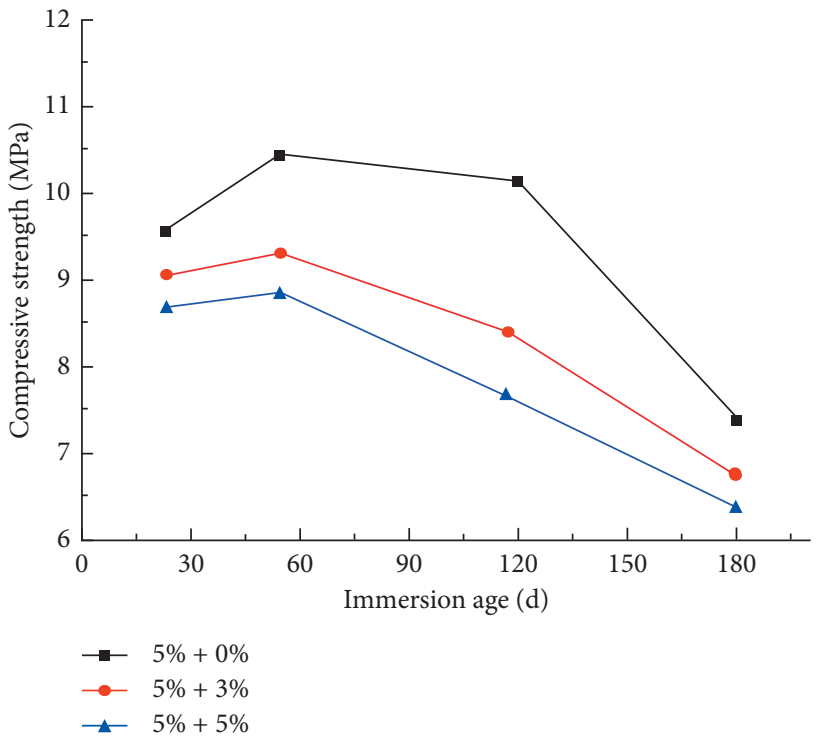

(b)

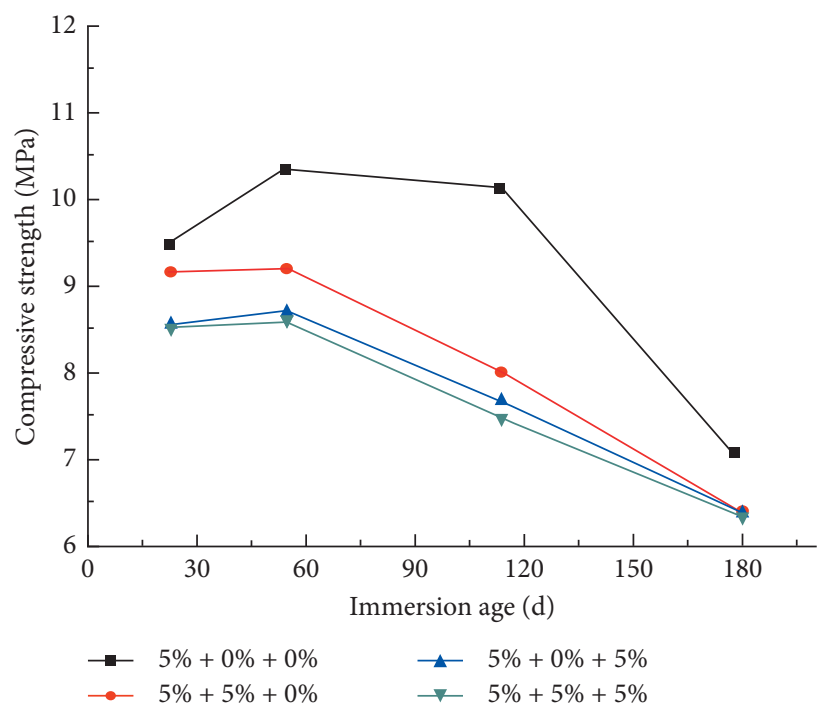

(c)

FIGURE 6: Effect of different ions on compressive strength of $\mathrm{SO}_{4}{ }^{2-}$ in CGBM. (a) $\mathrm{Na}_{2} \mathrm{SO}_{4}+\mathrm{MgSO}_{4}$, (b) $\mathrm{Na}_{2} \mathrm{SO}_{4}+\mathrm{NaHCO}_{3}$, and (c) $\mathrm{Na}_{2} \mathrm{SO}_{4}+5 \% \mathrm{MgSO}_{4}+5 \% \mathrm{NaHCO}_{3}$.

TABLE 4: Comparing diffusion coefficients of $\mathrm{SO}_{4}{ }^{2-}$ with or without consideration of time in CGBM.

\begin{tabular}{|c|c|c|c|c|c|}
\hline \multirow{2}{*}{ Specimens number } & \multirow[b]{2}{*}{$m$} & \multicolumn{2}{|c|}{ Considering time } & \multicolumn{2}{|c|}{ Regardless of time } \\
\hline & & $D_{1}\left(\times 10^{-7} \mathrm{~cm}^{2} / \mathrm{s}\right)$ & Var. & $D_{\mathrm{c}}\left(\times 10^{-7} \mathrm{~cm}^{2} / \mathrm{s}\right)$ & Var. \\
\hline S3 & 0.3689 & $1.8954 \times 10^{-5}$ & 1.1431 & 2.02502 & 2.6103 \\
\hline S5 & 0.5984 & $8.191 \times 10^{-4}$ & 1.6518 & 2.5845 & 2.795 \\
\hline S10 & 0.8354 & $3.8489 \times 10^{-3}$ & 1.4498 & 3.0405 & 2.8848 \\
\hline $\mathrm{S} 5+\mathrm{M} 3$ & 0.5577 & $6.0225 \times 10^{-4}$ & 0.8071 & 2.2837 & 1.5108 \\
\hline S5 + M5 & 0.6423 & $2.3004 \times 10^{-3}$ & 1.4091 & 2.8972 & 2.2574 \\
\hline $\mathrm{S} 5+\mathrm{H} 3$ & 0.6324 & $1.1047 \times 10^{-3}$ & 1.7244 & 2.8475 & 2.3421 \\
\hline $\mathrm{S} 5+\mathrm{H} 5$ & 0.6488 & $2.607 \times 10^{-3}$ & 1.684 & 3.0508 & 2.1764 \\
\hline $\mathrm{S} 5+\mathrm{M} 5+\mathrm{H} 5$ & 0.7724 & $4.315 \times 10^{-3}$ & 1.2453 & 3.2822 & 2.1909 \\
\hline
\end{tabular}


Table 5: The model of diffusion under the composite solutions.

\begin{tabular}{lc}
\hline Specimens number & Diffusion model \\
\hline S3 & $C(x, t)=0.4802\left[1-\operatorname{erf}\left(x / 615 t^{0.3155}\right)\right]$ \\
S5 & $C(x, t)=0.5539\left[1-\operatorname{erf}\left(x / 5072 t^{0.2008}\right)\right]$ \\
S10 & $C(x, t)=0.6833\left[1-\operatorname{erf}\left(x / 17175 t^{0.0823}\right)\right]$ \\
S5 + M3 & $C(x, t)=0.5183\left[1-\operatorname{erf}\left(x / 4144 t^{0.2211}\right)\right]$ \\
S5 + M5 & $C(x, t)=0.5421\left[1-\operatorname{erf}\left(x / 9007 t^{0.1788}\right)\right]$ \\
S5 + H3 & $C(x, t)=0.5346\left[1-\operatorname{erf}\left(x / 6157 t^{0.1838}\right)\right]$ \\
S5 + H5 & $C(x, t)=0.5941\left[1-\operatorname{erf}\left(x / 9677 t^{0.1756}\right)\right]$ \\
S5 + M5 + H5 & $C(x, t)=0.6221\left[1-\operatorname{erf}\left(x / 15464 t^{0.1138}\right)\right]$ \\
\hline
\end{tabular}

and XRD were used to observe the microstructure of reaction products. Test results are shown in Figure 7.

It can be observed from Figure 7(a) that the internal structure is complete, which contains a large amount of calcium hydroxide $\left(\mathrm{Ca}(\mathrm{OH})_{2}\right)$. Observe Figure $7(\mathrm{~b})$ and find that, when immersed in a solution containing $\mathrm{SO}_{4}^{2-}$, the $\mathrm{Ca}(\mathrm{OH})_{2}$ concentration is reduced and the calcium carbonate $\left(\mathrm{CaCO}_{3}\right)$ is increased, and there are ettringite and gypsum formation. Its chemical reaction is as follows:

$$
\begin{aligned}
& \mathrm{Ca}(\mathrm{OH})_{2}+\mathrm{SO}_{4}^{2-}+2 \mathrm{H}_{2} \mathrm{O} \longrightarrow \mathrm{CaSO}_{4} \cdot 2 \mathrm{H}_{2} \mathrm{O}+2 \mathrm{OH}^{-} \\
& 3 \mathrm{CaO} \cdot 2 \mathrm{SiO}_{2} \cdot 3 \mathrm{H}_{2} \mathrm{O}+3 \mathrm{SO}_{4}^{2-}+8 \mathrm{H}_{2} \mathrm{O} \\
& \quad \longrightarrow 3\left(\mathrm{CaSO}_{4} \cdot 2 \mathrm{H}_{2} \mathrm{O}\right)+6 \mathrm{OH}^{-}+2 \mathrm{SiO}_{2} \cdot \mathrm{H}_{2} \mathrm{O}
\end{aligned}
$$

It can be observed from Figure $7(\mathrm{c})$ that there is much columnar crystal in CGBM after corrosion with $\mathrm{SO}_{4}^{2-}$ and $\mathrm{Mg}^{2+}$ for $180 \mathrm{~d}$ [28], which is arranged orderly. At the same time, a large amount of amorphous matter is wrapped around the columnar crystal [29], its main products are $\mathrm{Mg}(\mathrm{OH})_{2}$, gypsum, ettringite, and $\mathrm{M}-\mathrm{S}-\mathrm{H}$. The diffraction peaks intensity of $\mathrm{M}-\mathrm{H}-\mathrm{S}$ and $\mathrm{Mg}(\mathrm{OH})_{2}$ is low in the low concentration solutions. It is verified that the formation of $\mathrm{Mg}(\mathrm{OH})_{2}$ can improve sulfate resistance of CGBM in the early composite solutions, so the compressive strength is increased. The number of diffraction peaks of M-H-S and $\mathrm{Mg}(\mathrm{OH})_{2}$ is increased when CGBM is immersed in composite solutions for $180 \mathrm{~d}$, and the high concentration solutions have higher diffraction peaks intensity. In addition, there are also $\mathrm{CaCO}_{3}$ and gypsum with large diffraction peaks intensity. It is indicated that as the concentration of $\mathrm{Mg}^{2+}$ increases and the corrosion time prolongs, $\mathrm{SO}_{4}^{2-}$ and $\mathrm{Mg}^{2+}$ continuously invade CGBM to form $\mathrm{CaSO}_{4}$. When the protective film of $\mathrm{Mg}(\mathrm{OH})_{2}$ is eroded, $\mathrm{SO}_{4}^{2-}$ and $\mathrm{Mg}^{2+}$ continuously infiltrate into the interior of CGBM. The C-H$\mathrm{S}$ is decomposed to form M-H-S without bond properties, making the structure of CGBM worse. Its chemical reaction is as follows:

$$
\begin{aligned}
& \mathrm{Na}_{2} \mathrm{SO}_{4}+\mathrm{Ca}(\mathrm{OH})_{2}+2 \mathrm{H}_{2} \mathrm{O}=2 \mathrm{NaOH}+\mathrm{CaSO}_{4} \cdot 2 \mathrm{H}_{2} \mathrm{O} \\
& \mathrm{MgSO}_{4}+\mathrm{Ca}(\mathrm{OH})_{2}+2 \mathrm{H}_{2} \mathrm{O}=\mathrm{Mg}(\mathrm{OH})_{2}+\mathrm{CaSO}_{4} \cdot 2 \mathrm{H}_{2} \mathrm{O} \\
& \mathrm{MgSO}_{4}+\mathrm{CaO} \cdot \mathrm{SiO}_{2} \cdot \mathrm{H}_{2} \mathrm{O} \longrightarrow \mathrm{MgO} \cdot \mathrm{SiO}_{2} \cdot \mathrm{H}_{2} \mathrm{O}+\mathrm{CaSO}_{4}
\end{aligned}
$$

It can be observed from Figure $7(\mathrm{~d})$ that a large amount of flocculent material forms in CGBM after corrosion with $\mathrm{SO}_{4}^{2-}$ and $\mathrm{HCO}_{3}^{-}$for $180 \mathrm{~d}$. In addition, there is much columnar crystal arranged disorderly, which is dispersed in the middle of flocculent material. The flocculent material is gypsum, ettringite, $\mathrm{C}-\mathrm{S}-\mathrm{H}$, and thaumasite. After immersing for 30 days, the diffraction peaks intensity of $\mathrm{Ca}(\mathrm{OH})_{2}$ is large; it is the hydration product of CGBM. CGBM is immersed in $\mathrm{SO}_{4}^{2-}$ and $\mathrm{HCO}_{3}^{-}$composite solutions, and the reaction product is $\mathrm{CaCO}_{3}$ and thaumasite. After $180 \mathrm{~d}$, the number of diffraction peaks of ettringite and gypsum increases significantly, and the diffraction peaks intensity of $\mathrm{CaCO}_{3}$ and thaumasite is also increased significantly. Under long-term effects, $\mathrm{Ca}(\mathrm{OH})_{2}$ is increasing because Portland cement contains more $\mathrm{C}_{2} \mathrm{~S}$ and its hydration product is enough, which provides enough reactants to form thaumasite, and CGBM is gradually corroded. Its internal structure is attacked seriously compared to a single sulfate.

Most studies on the formation of thaumasite show that it is easy to form at temperatures below $15^{\circ} \mathrm{C}$, especially at $4^{\circ} \mathrm{C}$ to $5^{\circ} \mathrm{C}$. However, in recent years, many studies have shown that thaumasite can still be formed at temperatures above $15^{\circ} \mathrm{C}$. According to Brown's research, thaumasite can also be formed at room temperature [33]. Juanhong Liu et al. found that water-rich filling materials in the sodium carbonate solution at a temperature of about $20^{\circ} \mathrm{C}$ generated a large amount of carbon thaumasite [34]. Cemented gangue backfill material (CGBM) also formed thaumasite at room temperature.

Its chemical reaction is as follows:

$$
\begin{aligned}
& \mathrm{NaHCO}_{3}+\mathrm{Ca}(\mathrm{OH})_{2} \longrightarrow \mathrm{CaCO}_{3}+\mathrm{H}_{2} \mathrm{O}+\mathrm{NaOH} \\
& \mathrm{C}_{3} \mathrm{~S}_{2} \mathrm{H}_{3}+2\left(\mathrm{CaSO}_{4} \cdot 2 \mathrm{H}_{2} \mathrm{O}\right)+2 \mathrm{CaCO}_{3}+24 \mathrm{H}_{2} \mathrm{O} \\
& \longrightarrow 2\left[\mathrm{Ca}_{3} \mathrm{SiSO}_{4} \mathrm{CO}_{3}(\mathrm{OH})_{6} \cdot 12 \mathrm{H}_{2} \mathrm{O}\right]+\mathrm{Ca}(\mathrm{OH})_{2} \\
& \mathrm{C}_{3} \mathrm{~S}_{2} \mathrm{H}_{3}+3 \mathrm{CaO} \cdot \mathrm{Al}_{2} \mathrm{O}_{3} \cdot 3 \mathrm{CaSO}_{4} \cdot 32 \mathrm{H}_{2} \mathrm{O}+2 \mathrm{CaCO}_{3} \\
& +4 \mathrm{H}_{2} \mathrm{O} \longrightarrow 2\left[\mathrm{Ca}_{3} \mathrm{SiSO}_{4} \mathrm{CO}_{3}(\mathrm{OH})_{6} \cdot 12 \mathrm{H}_{2} \mathrm{O}\right]+\mathrm{CaSO}_{4} \\
& \cdot 2 \mathrm{H}_{2} \mathrm{O}+2 \mathrm{Al}(\mathrm{OH})_{3}+4 \mathrm{Ca}(\mathrm{OH})_{2}
\end{aligned}
$$

It can be observed from Figure 7(e) that there is much columnar crystal neatly arranged in CGBM when CGBM is etched by $\mathrm{SO}_{4}^{2-}, \mathrm{Mg}^{2+}$, and $\mathrm{HCO}_{3}{ }^{-}$for $180 \mathrm{~d}$ [35-37]. The crystal is sharp and angular, and the surface is straight and smooth. In addition, there are M-S-H, C-S-H, gypsum, ettringite, and thaumasite in CGBM. And the number of diffraction peaks of ettringite and gypsum increases at $180 \mathrm{~d}$. At the same time, the diffraction peaks intensity of M-H-S and thaumasite is increased significantly. When $\mathrm{SO}_{4}^{2-}, \mathrm{Mg}^{2+}$, and $\mathrm{HCO}_{3}^{-}$exist simultaneously, the hydration product of the cement is $\mathrm{OH}^{-}$in CGBM, which combines with the soluble metal cation to produce more harmful corrosion products [38]. It can reduce the alkalinity of cement and decompose hydrated gel gradually. The corrosion products decompose the structure of CGBM, resulting in loss of its strength. 

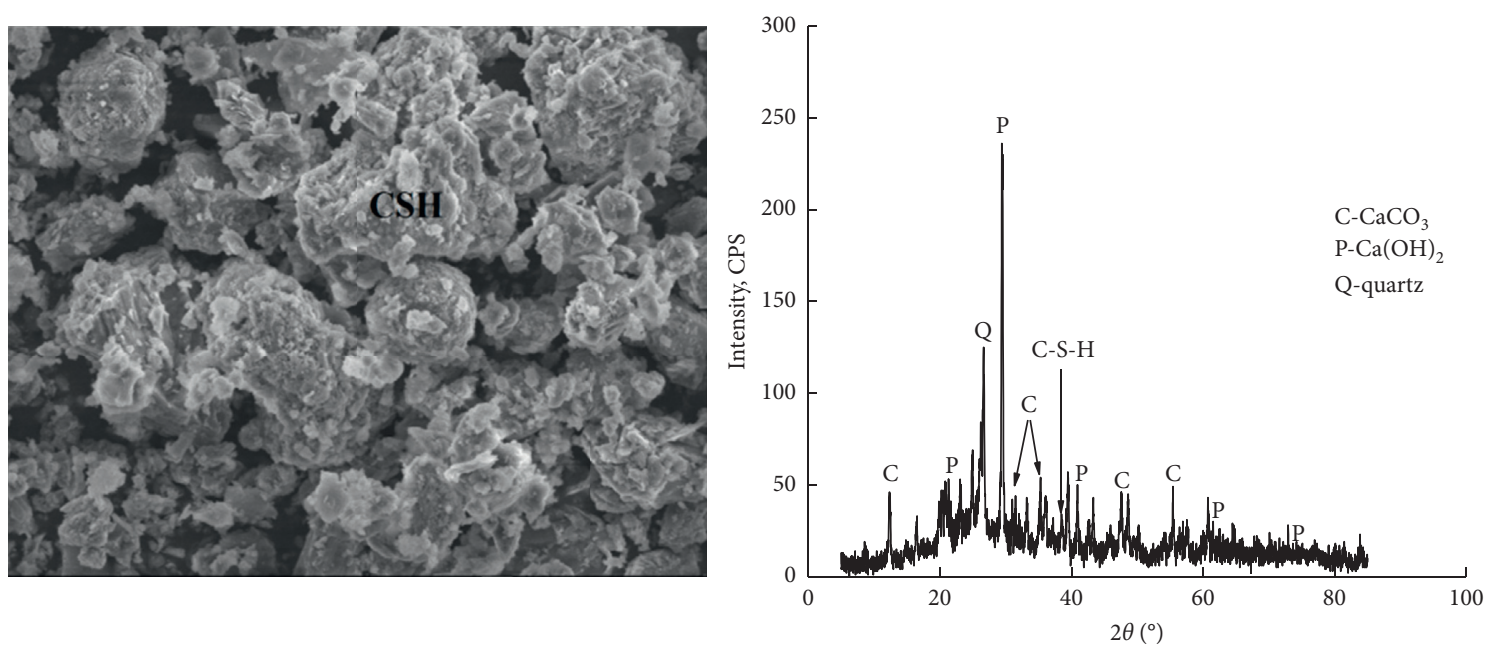

(a)
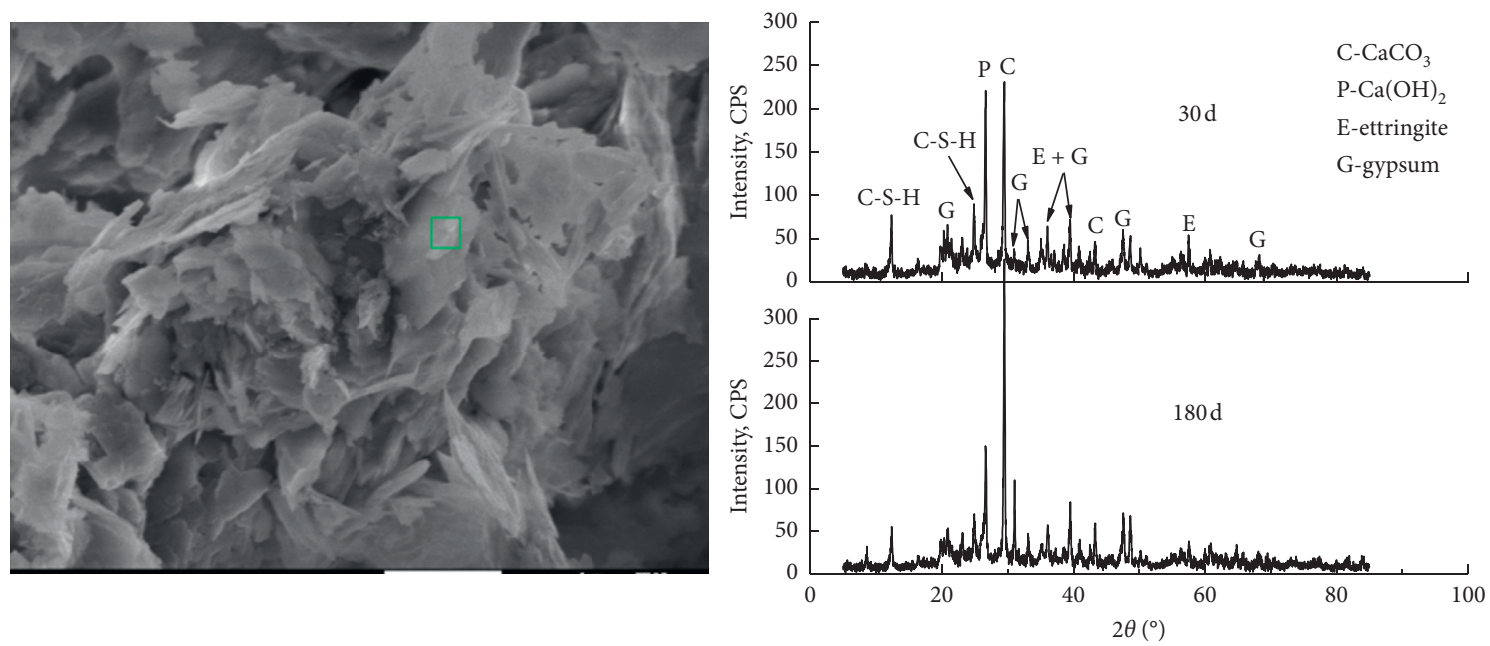

(b)
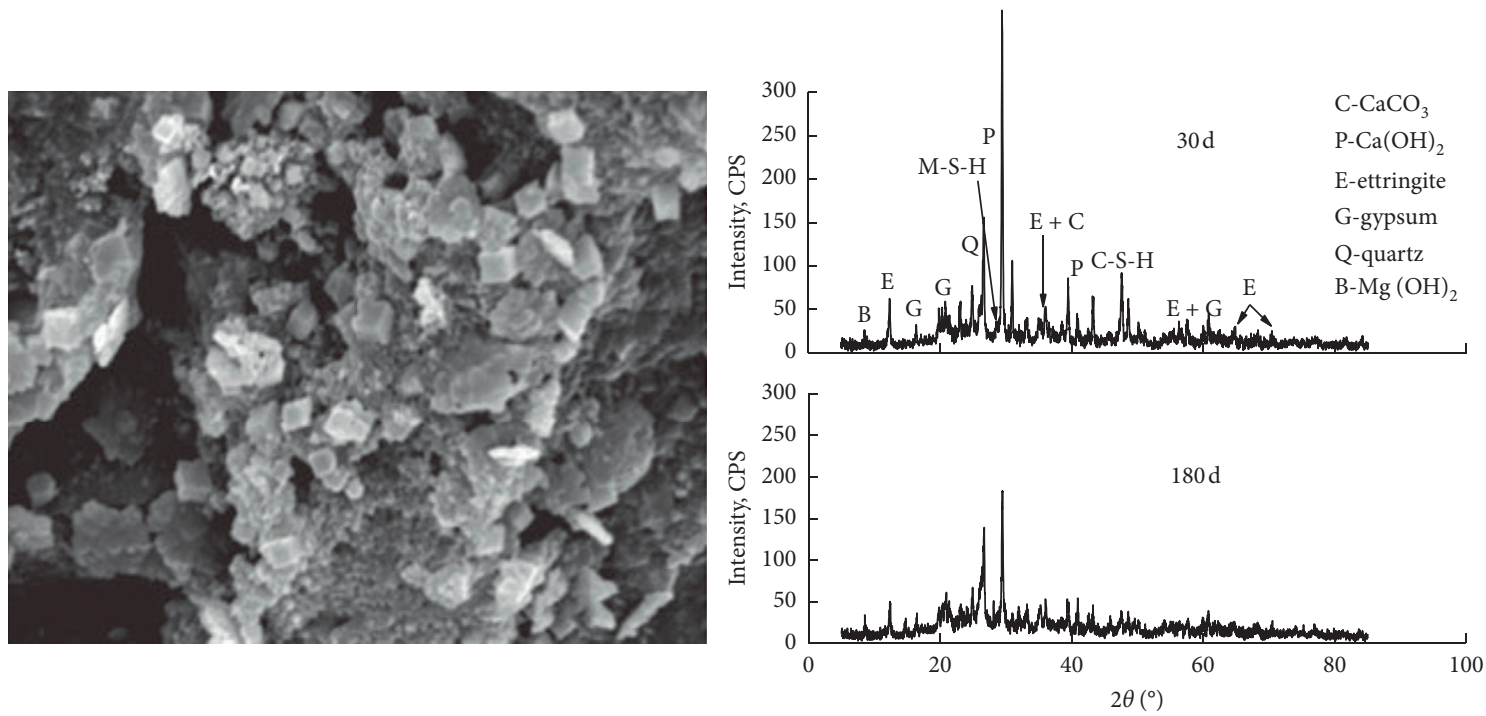

(c)

Figure 7: Continued. 

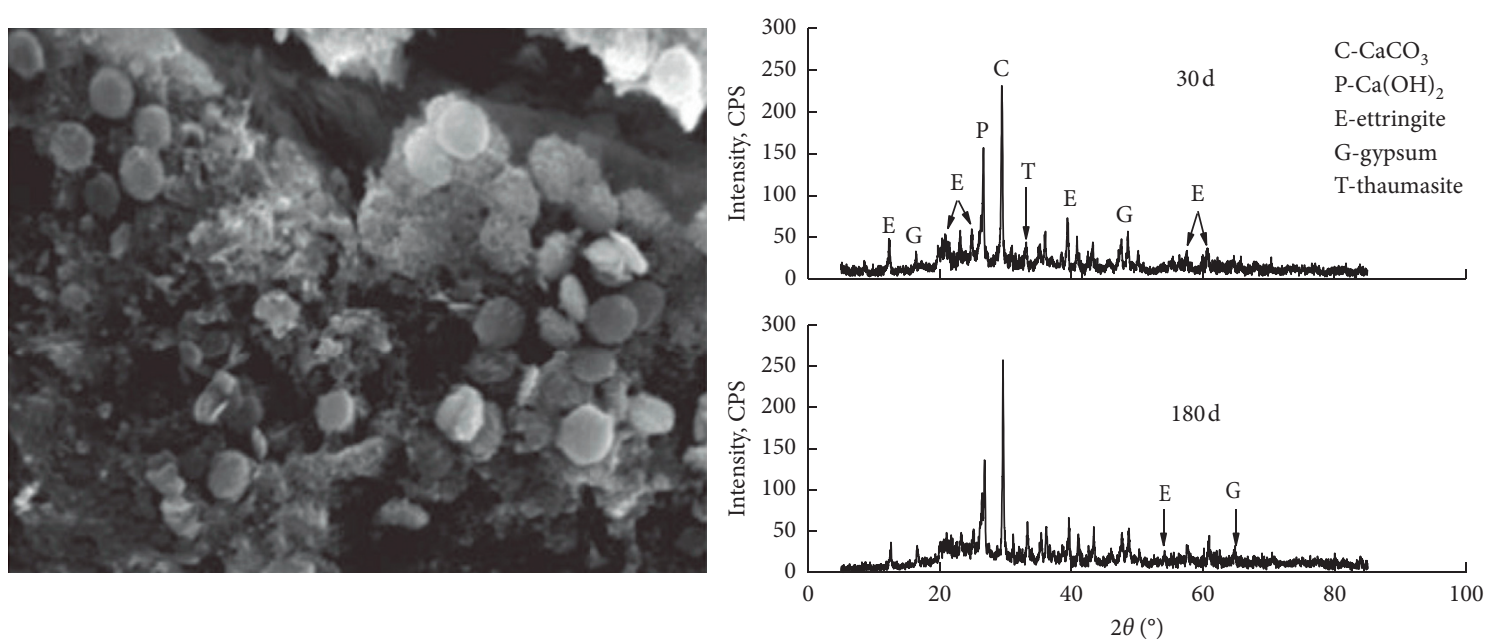

(d)
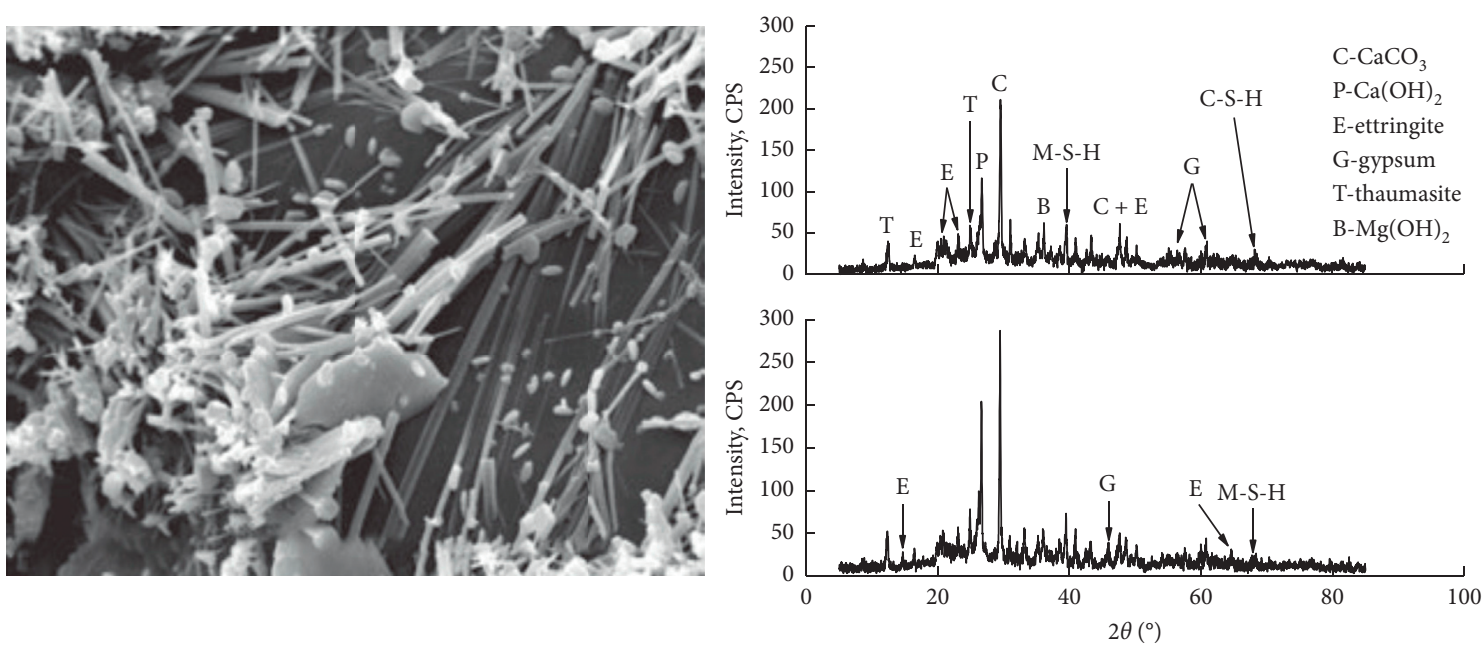

(e)

FIgURE 7: SEM images (180 d) and XRD patterns of CGBM immersed in different solutions. (a) Uneroded, (b) $5 \% \mathrm{Na}_{2} \mathrm{SO}_{4}$ solution, (c) $5 \%$ $\mathrm{Na}_{2} \mathrm{SO}_{4}+5 \% \mathrm{MgSO}_{4}$ composite solution, (d) $5 \% \mathrm{Na}_{2} \mathrm{SO}_{4}+5 \% \mathrm{NaHCO}_{3}$ composite solution, and (e) $5 \% \mathrm{Na}_{2} \mathrm{SO}_{4}+5 \% \mathrm{MgSO}_{4}+5 \%$ $\mathrm{NaHCO}_{3}$ composite solution.

\section{Conclusion}

Based on the results presented in this paper, the following conclusions are offered:

(1) The $\mathrm{SO}_{4}^{2-}$ concentration increases in CGBM when the external sulfate solutions concentration increases. At the early corrosion age, adding less than $3 \% \mathrm{Mg}^{2+}$ in external solutions can inhibit the diffusion of $\mathrm{SO}_{4}^{2-}$ in CGBM. As time goes on, adding $\mathrm{Mg}^{2+}$ and $\mathrm{HCO}^{-}$can accelerate the diffusion of $\mathrm{SO}_{4}^{2-}$.

(2) $\mathrm{Mg}^{2+}$ and $\mathrm{HCO}_{3}^{-}$have different effects on $\mathrm{SO}_{4}^{2-}$ diffusion rate; $\mathrm{Mg}^{2+}$ and $\mathrm{HCO}_{3}{ }^{-}$composite solutions have the greatest impact, $\mathrm{HCO}_{3}{ }^{-}$composite solutions have the second, and $\mathrm{Mg}^{2+}$ composite solutions have minimal.

(3) Gypsum and ettringite are formed by the reaction of $\mathrm{SO}_{4}{ }^{2-}$ into the CGBM. In the early 60 days, the reaction product will block the pores on the surface of the material, delay the diffusion reaction speed of the ions, and lead to an increase in strength. After 60 days, due to the increase of reaction products, the pores inside the material expand, which accelerates the diffusion reaction of ions, resulting in a decrease in strength.

(4) Diffusion coefficient of $\mathrm{SO}_{4}^{2-}$ is function related with time. As time goes on, the diffusion coefficient of $\mathrm{SO}_{4}^{2-}$ decreases gradually with an exponential function. Effect of time should be considered when predicting depth of $\mathrm{SO}_{4}^{2-}$ diffusion in CGBM.

\section{Data Availability}

The data used to support the findings of this study are included within the article.

\section{Conflicts of Interest}

The authors declare that they have no conflicts of interest. 


\section{Acknowledgments}

This work would have been difficult to complete without the support of the Joint Research Fund under cooperative agreement between the National Natural Science Foundation of China (NSFC) and the National Natural Science Foundation of China (nos.51574172 and 51804208), the Program for the Excellent Innovation Team of Higher Learning Institutions of Shanxi Province, the Applied Basic Research Project of Shanxi Province (201801D121092), the National Natural Science Foundation of China (no.51974192), and the Graduate Innovation Project of Shanxi Province (2019SY123).

\section{References}

[1] Z. G. Ma, J. Q. Fan, K. Sun et al., "Study on stop stability during repeated mining with fully-mechanized solid filling technology in residual coal pillar area," Joumal of Miningersafety Engineering, vol. 28, no. 4, pp. 499-504, 2011.

[2] G. Y. Feng, X. J. Du, Y. X. Guo et al., "Basic theory of constructional backfill mining and the underground space utilization concept," Journal of China Coal Society, vol. 44, no. 1, pp. 74-84, 2018.

[3] X. Du, G. Feng, Y. Guo, T. Qi, Y. Zhang, and J. Guo, "Failure analyses of unconfined CCWBM body in uniaxial compression based on central pressure variation," Waste Management \& Research, vol. 36, no. 2, pp. 159-168, 2018.

[4] T. Qi, G. Feng, Y. Li, Y. Guo, and Y. Zhang, "Effects of fine gangue on strength, resistivity, and microscopic properties of cemented coal gangue backfill for coal mining," Shock and Vibration, vol. 2015, Article ID 752678, 11 pages, 2015.

[5] X. N. Zhang, "Harm and prevention measures of acid mine water in coal mine," Shanxi Chemical Industry, vol. 37, no. 5, 2017.

[6] S. U. Al-Dulaijan, "Sulfate resistance of plain and blended cements exposed to magnesium sulfate solutions," Construction and Building Materials, vol. 21, no. 8, pp. 1792-1802, 2007.

[7] M. Fall and M. Benzaazoua, "Modeling the effect of sulphate on strength development of paste backfill and binder mixture optimization," Cement and Concrete Research, vol. 35, no. 2, pp. 301-314, 2005.

[8] Q. Sun, X. L. Li, X. Wei et al., "Strength evolution rule of filling past under the coupling influence of corrosion and maintenance," Bulletin of the Chinese Ceramic Society, vol. 34, no. 6, pp. 1480-1484, 2015.

[9] J. X. Zhao, W. B. Zhu, J. Zhang et al., "Experimental research on strength loss rules of C60 concrete in sulfate and carbonate composite salt disasters solutions," China Building Materials Science \& Technology, vol. 23, no. 3, pp. 48-50, 2014.

[10] B. Bary, N. Leterrier, E. Deville, and P. Le Bescop, "Coupled chemo-transport-mechanical modelling and numerical simulation of external sulfate attack in mortar," Cement and Concrete Composites, vol. 49, pp. 70-83, 2014.

[11] X. Wang, Z. Pan, X. Shen, Y. Chen, and W. Liu, "Diffusion characteristic of sulfate anion in surface region of cement mortar at early stage," Journal of Wuhan University of Technology-Materials Science Edition, vol. 32, no. 2, pp. 358-364, 2017.

[12] X. B. Zuo and W. Sun, "Simulations on sulfate ion diffusivity in concrete column under random excitations," Advanced Materials Research, vol. 261-263, pp. 275-279, 2011.
[13] A. E. Idiart, C. M. López, and I. Carol, "Chemo-mechanical analysis of concrete cracking and degradation due to external sulfate attack: a meso-scale model," Cement and Concrete Composites, vol. 33, no. 3, pp. 411-423, 2011.

[14] T. Ikumi, S. H. P. Cavalaro, I. Segura, and A. Aguado, "Alternative methodology to consider damage and expansions in external sulfate attack modeling," Cement and Concrete Research, vol. 63, pp. 105-116, 2014.

[15] N. Cefis and C. Comi, "Chemo-mechanical modelling of the external sulfate attack in concrete," Cement and Concrete Research, vol. 93, pp. 57-70, 2017.

[16] H. Justnes, M. O. Kim, S. Ng, and X. Qian, "Methodology of calculating required chloride diffusion coefficient for intended service life as function of concrete cover in reinforced marine structures," Cement and Concrete Composites, vol. 73, pp. 316-323, 2016.

[17] Z. M. Ma, Z. H. Duan, and G. Z. Ba, "Effects of an applied load on the chloride penetration of concrete with recycled aggregates and recycled powder," Advances in Civil Engineering, vol. 2019, Article ID 1340803, 15 pages, 2019.

[18] J. Zhang, J. Zhao, Y. Zhang, Y. Gao, and Y. Zheng, "Instantaneous chloride diffusion coefficient and its time dependency of concrete exposed to a marine tidal environment," Construction and Building Materials, vol. 167, pp. 225-234, 2018.

[19] Y. Wang, M. An, Z. Yu, B. Han, and W. Ji, "Experimental and cellular-automata-based analysis of chloride ion diffusion in reactive powder concrete subjected to freeze-thaw cycling," Construction and Building Materials, vol. 172, pp. 760-769, 2018.

[20] P. Vargas, N. A Marín, and J. I. Tobón, "Performance and microstructural analysis of lightweight concrete blended with nanosilica under sulfate attack," Advances in Civil Engineering, vol. 2018, Article ID 2715474, 11 pages, 2018.

[21] P. Koneny, P. Lehner, T. Ponikiewski, and P. Miera, "Comparison of chloride diffusion coefficient evaluation based on electrochemical methods," Procedia Engineering, vol. 190, pp. 193-198, 2017.

[22] M. Fall and M. Pokharel, "Coupled effects of sulphate and temperature on the strength development of cemented tailings backfills: Portland cement-paste backfill," Cement and Concrete Composites, vol. 32, no. 10, pp. 819-828, 2010.

[23] A. A. Abouhussien and A. A. A. Hassan, "Experimental and empirical time to corrosion of reinforced concrete structures under different curing conditions," Advances in Civil Engineering, vol. 2014, Article ID 595743, 9 pages, 2014.

[24] J. Zhang, M. Sun, D. Hou, and Z. Li, "External sulfate attack to reinforced concrete under drying-wetting cycles and loading condition: numerical simulation and experimental validation by ultrasonic array method," Construction and Building Materials, vol. 139, pp. 365-373, 2017.

[25] J. Stroh, M.-C. Schlegel, E. F. Irassar, B. Meng, and F. Emmerling, "Applying high resolution SyXRD analysis on sulfate attacked concrete field samples," Cement and Concrete Research, vol. 66, pp. 19-26, 2014.

[26] M. Zhang, L. M. Yang, J. J. Guo, W. L. Liu, and H. L. Chen, "Mechanical properties and service life prediction of modified concrete attacked by sulfate corrosion," Advances in Civil Engineering, vol. 2018, Article ID 8907363, 7 pages, 2018.

[27] Y. Tian, Z. Tian, N. Jin, X. Jin, and W. Yu, "A multiphase numerical simulation of chloride ions diffusion in concrete using electron microprobe analysis for characterizing properties of ITZ," Construction and Building Materials, vol. 178, pp. 432-444, 2018. 
[28] N. Thaulow and S. Sahu, "Mechanism of concrete deterioration due to salt crystallization," Materials Characterization, vol. 53, no. 2-4, pp. 123-127, 2004.

[29] B. Cui, Y. Liu, H. Guo, Z. Liu, and Y. Lu, "Experimental study on the durability of fly ash-based filling paste in environments with different concentrations of sulfates," Advances in Materials Science and Engineering, vol. 2018, Article ID 4315345, 12 pages, 2018.

[30] A. Costa and J. Appleton, "Chloride penetration into concrete in marine environment-Part II: prediction of long term chloride penetration," Materials and Structures, vol. 32, no. 5, pp. 354-359, 1999.

[31] E. F. Eraser, "Sulfate attack on cementitious materials containing limestone filler-A review," Cement and Concrete Research, vol. 39, no. 3, pp. 241-254, 2009.

[32] P. S. Mangat and B. T. Molloy, "Prediction of long term chloride concentration in concrete," Materials and Structures, vol. 27, no. 6, pp. 338-346, 1994.

[33] P. W. Brown, R. D. Hooton, and B. A. Clark, "The co-existence of thaumasite and ettringite in concrete exposed to magnesium sulfate at room temperature and the influence of blastfurnace slag substitution on sulfate resistance," Cement and Concrete Composites, vol. 25, no. 8, pp. 939-945, 2003.

[34] M. Gao, J. H. Liu, and A. X. Wu, "Corrosion and deterioration mechanism of water-rich filling materials in carbonate solutions," Journal of University of Science and Technology Beijing, vol. 8, pp. 976-983, 2015.

[35] A. Ipavec, R. Gabrovšek, T. Vuk, V. Kaučič, J. Maček, and A. Meden, "Carboaluminate phases formation during the hydration of calcite-containing Portland cement," Journal of the American Ceramic Society, vol. 94, no. 4, pp. 1238-1242, 2011.

[36] R. J. Flatt, "Salt damage in porous materials: how high supersaturations are generated," Journal of Crystal Growth, vol. 242, no. 3-4, pp. 435-454, 2002.

[37] T. Aye and C. T. Oguchi, "Resistance of plain and blended cement mortars exposed to severe sulfate attacks," Construction and Building Materials, vol. 25, no. 6, pp. 2988-2996, 2011.

[38] D. D. Higgins, "Increased sulfate resistance of ggbs concrete in the presence of carbonate," Cement and Concrete Composites, vol. 25, no. 8, pp. 913-919, 2003. 